|Araştırma Makalesi / Research Article|

\title{
Bir KAÇD’nin Tasarım ve Uygulama Sürecinin Eğitmen Deneyimleri Açısından İncelenmesi ${ }^{1}$ \\ Investigating the Design and Implementation Process of a MOOC through the Experiences of Instructors
}

\section{Seçil Tısoğlư ${ }^{2}$, Kadir Yücel Kaya ${ }^{3}$}

\begin{tabular}{l} 
Anahtar Kelimeler \\
KAÇD \\
çevrimiçi öğrenme \\
açık eğitim \\
eğitsel tasarım ve \\
uygulama \\
\hline
\end{tabular}

\section{Keywords}

MOOC

online learning

open education

educational design and implementation

\section{Başvuru Tarihi/Received}

03.07.2020

Kabul Tarihi /Accepted 30.11.2020

\begin{abstract}
Öz
Kitlesel Açık Çevrimiçi Dersler (KAÇD) eğitim alanındaki son yıllardaki gelişmelerde geniş ölçekli bir etkiye sahiptir. Bu derslerin tasarımı, özellikle çevrimiçi ve açık öğrenme kavramlarına yeni boyutlar kazandırmış ve öğretim tasarımı sürecine yönelik yeni bakış açılarının gelişmesine katkı sağlamıştır. Bilgi ve iletişim çağında değişen öğrenen ihtiyaçları, beklentileri ve profilleri de bu süreçte yeni tanımlamalar kazanmıştır. Öğrenen deneyimlerine yönelik çalışmalar mevcutken, geniş ölçekli olan bu derslerin tasarlanması ve bu sürecin öğreticiler açısından incelenmesine yönelik ise daha fazla çalışma yapılması gerektiği belirlenmiştir. Bu çerçevede, bu çalışmanın asıl amacı hem öğrenen hem de öğretici bakış açısına sahip olan kişilerin KAÇD ile ilgili yaşadıkları deneyimler dahilinde düşüncelerini, yaşadıkları zorlukları ve muhtemel çözüm önerilerini ortaya koymaktır. Çalışmanın ikincil amacı ise bir KAÇD ortamının tasarım ve uygulanma sürecini detaylı incelemektir. Bu amaçlar çerçevesinde, bu çalışma tekli durum çalışması olarak tasarlanmış olup, durum hayata geçirilen bir KAÇD ortamı olarak belirlenmiştir. Çalışma verileri bu dersin tasarım ve uygulama sürecinde yer alan 10 kişiden oluşmakta olup, veriler nitel veri analiz yöntemiyle yorumlanmıştır. Çalışmanın sonuçlarına göre hem öğrenen hem de eğitmen deneyimlerine yönelik görüşler genelde olumlu olup özellikle bu süreçlerin profesyonel, mesleki ve bireysel gelişime katkı sağladığı fikrinde uzlaşılmıştır. Öğrenen deneyimlerinde ortaya çıkan zorluklar iletişim, motivasyon başlıklarında toplanırken, eğitmenlerin yaşadıkları zorluklar ise tasarım, uygulama ve değerlendirme başlıkları altında incelenmiştir. Bu çalışmada ortaya çıkan sonuçlara göre, öncesinde çevrimiçi öğrenme deneyimi olan eğitmenlerin KAÇD ortamını tasarlama sürecinde karşılaştıkları zorluklar, bu tarz öğrenme ortamların nasıl tasarlanacağından ziyade yüksek katılımcı sayısının beraberinde getirdiği yeni durumlarla nasıl baş edeceklerine yönelik durumlar ve stratejileri içermektedir.

\section{Abstract}

Massive Open Online Courses (MOOC) had a vast scale effect on recent developments in the field of education. Especially online and open learning concepts have gained new aspects from the design of these courses and it has contributed to develop new perspectives towards instructional design process. Changing learner needs, expectations and characteristics has acquired new meanings in the information age. There are many studies towards learner experience, however, there is a need for more studies about designing these massive courses and examining the process from the instructor perspective. In this regard, main purpose of this study is to reveal the opinions, challenges, and solutions about the MOOC experiences of people who have both the learner and instructor perspective. Secondary purpose of the study is to examine the design and implementation process of a MOOC environment in detail. In the light of these purposes, this study is designed as a single case study, and the case is specified as a MOOC environment that was put into practice. Participants of the study consisted of 10 people who were in the design and implementation of a MOOC platform and the data were analyzed with qualitative analysis methodology. Results of the study put forward that opinions were generally positive about the MOOC experience from both learner and instructor perspectives, and it was agreed that the process contributed the development of professional and personal development of the participants. Challenges emerged related with the participants' past learner experience are communication, lack of motivation, on the other hand, main challenges faced during the design and implementation process investigated around design, implementation and evaluation aspects. According to the results of this study, the challenges faced by instructors who have online learning experience in advance concentrated on states and strategies on how to deal with the new situations and problems introduced by the number of learners rather than how to design the MOOC environment.
\end{abstract}

\footnotetext{
${ }^{1}$ Bu çalışmanın bir kısmı 26. EDEN Yıllık Konferansında sunulmuştur.

${ }^{2}$ Kastamonu Üniversitesi, Eğitim Fakültesi, Eğitim Bilimleri Bölümü, Kastamonu, TÜRKiYE; https://orcid.org/0000-0001-5668-3769

${ }^{3}$ Sorumlu Yazar, Kastamonu Üniversitesi, Eğitim Fakültesi, Eğitim Bilimleri Bölümü, Kastamonu, TÜRKiYE; https://orcid.org /0000-0001-7561-980X
}

Alıntı/Citation: Tısoğlu, S., \& Kaya, K. Y. (2020). Bir KAÇD’nin tasarım ve uygulama sürecinin eğitmen deneyimleri açısından incelenmesi. Kastamonu Education Journal, 28(6), 2535-2551. doi: 10.24106/kefdergi.763555 


\section{Extended Abstract}

\section{Introduction}

Throughout history, technology has played an important role on educational practices. One of the recent applications related to the technology integration into education is Massive Open Online Courses (MOOC). MOOC term was first used in the course as "Connectivism and Connective Knowledge" by George Siemens and Stephen Downes in 2008 (Conole, 2013; Yuan \& Powell, 2013). After this year, many institutions and companies have provided different MOOC environments through worldwide. Two approaches shaped the $\mathrm{MOOC}$ movement which enable more hybrid approach to address the $21^{\text {st }}$ century problems on education. Online education and its antecedent distance education provide the structure on how to convey instruction through internet. On the other hand, open education which evolved behind the idea of openness serves the idea of flexible, free access to education. Therefore, MOOCs are mostly referred to a blended version of online and open education approaches. However, the arguments about the distinction between MOOCs and the approaches are highly mentioned in the literature (Allen \& Seaman, 2014; Wiley, 2014; Stracke et al., 2019).

MOOCs are the cooperative and collaborative environments that enable the participants to select courses through their needs and motivations (Milheim, 2103). In addition, MOOCs create a social environment that gathers many participants to organize and determine their learning environment and needs (McAuley, Stewart, Siemens \& Cormier, 2010). There are some contradicting ideas about the benefits and the challenges of the MOOC practices. Yuan and Powell (2013) summarized the challenges in terms of sustainability, quality, pedagogical problems, completion and motivation. Similarly, Milheim (2013) and Richter and Krishnamurthi (2014) criticized the challenges as the completion rates, financial problems of creating and providing the courses, certification problems and reliability and the validity of the students' performances. Other problem is related to the assessment. Richter and Krishnamurthi (2014) and Spector (2014) explained the assessment problems as the difficulty for evaluating many people and giving appropriate and detailed feedback. Spector (2014) also argued that MOOCs could not yet provide instructional objects through intentionally designed activities. Moreover, social issues in MOOC environments are a critical challenge. Therefore, the methods for the social learning and support in this environment are still a problem (Bates, 2014). In general, designing, creating and implementing a MOOC environment holds potential issues and challenges for the instructors. Enlightening these challenges could be important for the future designs and providing potential solutions could guide the way.

\section{Method}

This research was designed through single case study method (Yin, 2009) to analyze the participants' experiences on the MOOC environment. The case of this study was selected as a MOOC which was designed by a professor in a state university on Southeast part of USA. The participants were the professor, the doctoral students and teaching assistants at that university who created a MOOC environment. 10 participants who had designed, developed and utilized the course was selected. Most of the participants (8 of 10) had learner experience on MOOCs in advance. The course, SMOOC (Social Media for Active Learning MOOC), which was presented in 2014/2015 as 4 weeks course, was investigated for the purposes of this research. The research questions were also defined based on the purposes which address to explore the experiences of participants on MOOC environment through learner and instructor's perspective, and to investigate the principles and processes on how to design and utilize a MOOC environment. The process of this research was developed through two phases. In the first phase (observation), researchers observed the MOOC environment in order to investigate the activities, materials, students' behaviors, and management issues. In the second phase (interview), interviews were conducted with the participants. The results were analyzed through qualitative analysis method as Creswell (2012) suggested.

\section{Result and Discussion}

Three research questions shaped the result of this study. First part derived from the learner's perspective. Participants' main motives to attend MOOCs were to find supplementary materials, and to improve their teaching ideas. Related with the advantages of MOOCs from learners' side, easy access, flexibility, free of charges and expanding community of practice were prominent factors. Regarding challenges through learning experience were stated as limited interaction, lack of self-motivation, lack of certificate-degree and concerns about plagiarism. On the other hand, from the instructors' perspective, MOOCs have advantages on their professional development and online education perspective. Three stages emerged regarding the challenges while designing and managing the course: design, implementation and evaluation. To define a specific topic and provide guideline, quality of the content and the assessment (especially qualitative evaluation, discussion boards and social media activities) were highly stated issues. Furthermore, other challenges were mostly related with lack of time and highly-intensive workforce. In addition, the cost of the course was one of the criticized issues related to the workforce and sustainability of the course. For social interaction, many activities were used. Additionally, the quality of the grading system and the qualitative evaluation were also mentioned to consider. Lastly, the number of students and their background were issues to handle while designing the course but the team developed some strategies to address the challenges. Therefore, these strategies/solutions and the experiences of instructors who also have learner experiences could enlighten the future developments and studies about MOOCs. 


\section{GiRiş}

Yeni teknolojiler ve bu teknolojilerin eğitim alanıyla olan ilişkisi, yeni yaklaşımlar ve uygulamaların önünü açmaktadır. Son yıllarda teknoloji dahilinde evrimleşen eğitim yaklaşımı, öğrenmenin farklı boyutlarda değerlendirilmesine olanak tanımaktadır. Yeni nesil öğrenme yaklaşımlarındaki odak noktaları, özellikle sosyal ve işbirlikli öğrenme, dijital ve kaynakça zengin öğrenme, ücretsiz, açık, çevrimiçi ve gayri resmî öğrenme ile bireysel düzenleme gibi kavramları kapsamakta ve ihtiyaç ve isteklere yönelik büyük öğrenme ortamlarını ve deneyimlerini içermektedir (Bonk, 2016). Öğrenmenin geniş kitlelere ulaştırılması ve her kesimin erişimine açık olması fikri, temelde uzaktan öğrenme yaklaşımından beslenen çevrimiçi öğrenme ve herkese açıklık kavramından beslenen açık eğitim kavramlarını barındırmaktadır. Her iki yaklaşımı baz alan, geniş kitlelerin erişimine açılan ücretsiz ve açık dersler (Pilli ve Admiraal, 2016) ile eğitim sahnesine çıkan Kitlesel Açık Çevrimiçi Ders (KAÇD/MOOC) yaklaşımı, yeni nesil öğrenme ortamları ve öğrenen beklentilerini karşılamayı amaçlamıştır. Gelişen teknolojiyle ve bireysel, sosyal ve toplumsal dönüşüm dahilinde değişen beklentilerle beraber öğretim sürecinin daha öğrenen odaklı, bireysel, sosyal, profesyonel becerilere ve amaçlara odaklanan bir yapıya evrilmesi özellikle yükseköğretim kurumlarındaki geleneksel yapının değişimine katkı sağlamıştır. Bu değişim süreci de üniversitelerin daha popüler veya bilinir olmasına, üniversiteler arası rekabetin ve kalite algısının artırılmasına yönelik çalışmalara yol açmıştır (O'Connor, 2014).

2008 yılından bu yana tüm dünyada KAÇD uygulamalarının sayısı her geçen gün artmaktadır. Özellikle üniversitelerle iş birliğiyle zenginleştirilen platformlar (Coursera, edX vb.), bireysel eğiticilerle desteklenen organizasyonlar (Udacity, Udemy vb.), profesyonel gelişim ve mesleki yeterlilik odaklı platformlar (Bilgeiş), KAÇD hareketinin günümüze kadar gelen uygulamalarından bazılarıdır. 2012 yılında üniversitelerle iş birliği çerçevesinde sunulan platformların artmasıyla popülerleşen KAÇD (Xiong ve Suen, 2018), eğitimde büyük bir değişim yaratacağına dair beklentilerin ve bu uygulamaların etkileri üzerine yapılan bilimsel çalışmaların sayısının oldukça artmasına neden olmuştur (O'Connor, 2014). Ancak, son yıllarda yapılan çalışmalarda, araştırmacıların çoğunlukla nicel çalışmalara yöneldiği (Veletsianos ve Shepherdson, 2016) ve öğreticilerin deneyimleri, beklentileri ve görüşlerine yönelik çalışmaların oldukça az olduğu belirlenmiştir (Veletsianos ve Shepherdson, 2016; Lowenthal, Snelson ve Perkins, 2018; Askeroth ve Richardson, 2019). Ayrıca hem öğrenen hem de eğitmen deneyimine sahip katılımcıların her iki deneyimlerini de yorumlamalarına yönelik çalışma eksikliği göze çarpmaktadır. Öğrencilerin deneyim ve etkinliklerini iyileştirmek ve zenginleştirmek için çevrimiçi öğrenme ortamlarındaki deneyimleri ve davranışları önemli bir rol teşkil etmektedir. Ek olarak, KAÇD’in yeni uygulamalarında ve öğretimsel yönlerini anlama konusunda, dersi tasarlayanlar önemli bir rol taşımaktadır. Dolayısıyla bu çalışmadaki eğitmen ve öğrenci deneyimlerinin KAÇD ortamlarını geliştirme açısından önemli sorunları ve konuları ortaya koyabileceği düşünülmektedir. Temelde, her iki bakış açısına da sahip olan kişilerin deneyimlerini ortaya çıkarmak ve bu deneyimleri arasındaki ilişkiyi ortaya koymak, bu çalışmanın temel amacını oluşturmaktadır.

\section{Çevrimiçi Öğrenme ve Açık Eğitim Kaynakları}

Temelini yaklaşık 100 yıllık bir tarihi olan uzaktan eğitim yaklaşımından alan çevrimiçi öğrenme, internet ve web teknolojisinin gelişimiyle beraber eğitimin bu teknolojiler vasıtasıyla çoğunluğun erişimine sunulması yaklaşımını benimsemektedir (Means, Toyama, Murphy, Bakia ve Jones, 2010). 1990 yılından itibaren ise, çevrimiçi öğrenme ortamları eğitim uygulamalarında yerini almaya başlamıştır (Pilli ve Admiraal, 2016). Çevrimiçi öğrenme yaklaşımları, öğretime dahil olma zamanı açısından (senkron [öğretici ve öğrenenin aynı zaman zarfında dahil olduğu öğretim ortamı] veya asenkron) (öğretimin öğrenen ve öğreticinin farklı zamanlarda dahil olduğu öğrenme ortamı); öğretim amacı açısından (tamamen çevrimiçi ortamlar ve hibrit ortamlar); ve öğretim yaklaşımı açısından (açıklayıcı öğrenme, aktif öğrenme ve interaktif öğrenme) farklı kategorilerde değerlendirilebilmektedir (Means vd., 2010). Bunun yanı sıra öğretimin nasıl sunulacağına dair sunulan farklı metotlar olsa da, Allen ve Seaman'a (2014) göre çevrimiçi öğrenme perspektifinden bakıldığında öğretimin nasıl sunulacağına dair yaklaşımlar 4 kategoriye ayrılabilir: geleneksel (içerdiği çevrimiçi içerik/kaynak yüzdesi: 0\%), web destekli (içerdiği çevrimiçi içerik/kaynak yüzde aralığı: 1\%-29\%), hibrit (içerdiği çevrimiçi içerik/kaynak yüzde aralığı: 30\% - 79\%) ve çevrimiçi (içerdiği çevrimiçi içerik/kaynak yüzdesi aralığı: 80+\%). Çevrimiçi öğrenme genellikle yüz yüze öğrenme ortamlarına alternatif veya bu ortamlara destek olacak şekilde üretilen dersler olarak tanımlanmaktadır. (Means vd., 2010). Bu çerçevede, çevrimiçi öğrenme dinamikleri, unsurları ve yaklaşımlarını değerlendirdiğimizde KAÇD yaklaşımının bazı noktalarda farklılaştığı ortaya çıkmıştır. KAÇD ortamındaki öğrenen profili ve beklentileri, ücretsiz ve açık erişim vurgusu ve geleneksel ders ortamlarında farklı olarak sunduğu ölçme ve değerlendirme yöntemleri ile çevrimiçi öğrenme ortamlarından farklı bir çizgide ilerlemektedir (Allen ve Seaman, 2014). Bu noktada, çevrimiçi öğrenme genel anlamda yüz yüze öğrenme ortamında yer alan öğretim sürecindeki temel unsurlarla desteklenen bir yaklaşımı temsil ederken, KAÇD yaklaşımının ise çevrimiçi öğrenmenin bazı prensipleri yanında açıklık kavramı dahilinde yer alan açık eğitim ve açık eğitim kaynakları (AEK) yaklaşımlarını da gözeten bir öğretim yaklaşımını benimsediği söylenebilir.

Açıklık kavramı, içerisinde farklı unsurları barındıran kavramsal ve çok katmanlı bir yaklaşımı ifade etmektedir. Açıklık felsefesi temelde geç orta çağ döneminden günümüze kadar eğitimde var olan bir kavram olarak tanımlanırken, tarihsel süreç boyunca ekonomik, sosyal, kültürel ve teknolojik gelişmelerle evrimleşen bir yaklaşım olarak benimsenmiştir (Peter ve Deimann, 2013). Zaman içinde farklı tanımlamalar dahilinde yorumlanan açık eğitim kavramı ise, özellikle son 20 yılda ortaya çıkan AEK ve KAÇD hareketleri ile beraber eğitime erişimin genişletilmesi yaklaşımından yeniden kullanım, açık lisans ve açık paylaşım kavramlarına doğru evrilmiştir (Weller, Jordan, DeVries ve Rolfe, 2018). Bunun sonucunda, AEK ve KAÇD hareketleri benzer açık eğitim felsefesi üzerinden yorumlansa da açık erişim ve açık kaynak yazılımları açısından farklı bir rota izledikleri gözlemlenmektedir. ilkk defa 2001 yılında MIT tarafından hayata geçirilen Açık Ders Malzemeleri (ADM) projesiyle ders materyallerinin tüm kullanıcıların erişimine 
açık ve ücretsiz olarak sunulmasıyla, AEK hareketinin ilk adımı atılmış oldu. 2002 yılında ise UNESCO Forum'da Açık Eğitim Kaynakları kavramının ilk resmi tanımlaması yapıldı (D’Antoni, 2008; Duval ve Wiley, 2010; Murphy, 2013). Bu tarihten sonra özellikle açık kaynak ve açık erişim yaklaşımı üzerinden devam eden ve ADM uygulamalarında ve çeşitli platformlarda karşımıza çıkan AEK hareketinin gelecekteki uygulaması olarak KAÇD hareketi ortaya çıktı. 2008 yılında, George Siemens ve Stephen Downes tarafından oluşturulan Connectivism and Connective Knowledge isimli çevrimiçi ders, KAÇD uygulamalarının başlangıCı olarak kabul edilmektedir (Downes, 2012; Jacoby, 2014). Kitlesel çevrimiçi açık dersler kavramındaki kitlesel ifadesi geleneksel öğrenme ortamları ile kıyaslandığında yüksek katılımcı sayısına işaret ederken, çevrimiçi ifadesi 1990 yılından itibaren eğitimde kullanılmaya başlanan web tabanlı derslerin günümüzdeki kullanımını işaret etmektedir (Stracke et.al, 2019). Açık dersler kavramı ise bu hareket dahilindeki uygulamaları dolayısıyla tartışmalı olup, açık erişim, açık kaynak ve açık lisans kavramlarından beslenen AEK hareketinden (Wiley, 2014) farklı bir rota izlemektedir (Stracke vd., 2019). KAÇD yaklaşımı dahilindeki açıklık kavramı tüm öğrenenlere açık bir kayıt sistemi, ücretsiz içerik ve zaman kısıtlamasına tabi olmayan içerik erişimi, esnek öğretim program olarak tanımlanmaktadır (Sanchez-Gordon ve Lujan-Mora, 2014). Fakat çoğu KAÇD uygulamasında içeriğin ve materyalin açık kaynak koduyla paylaşılması veya içeriğin açık lisans ile diğer kullanıcılara sunulması konusunda AEK hareketinden farklı olarak açıklık felsefesiyle çelişen kısıtlamalar söz konusudur.

\section{Öğrenenlerin KAÇD Kullanma Nedenleri ve Deneyimleri}

Alanyazın tarandığında kullanıcıları KAÇD ortamlarını kullanmaya neyin güdülediğiyle ilgili birçok çalışma olduğu görülmektedir. Belanger ve Thornton'a (2013) göre öğrenenlerin KAÇD’yi kullanma motivasyonları; yaşam boyu öğrenmeyi desteklemek, tamamlama hedefi olmadan bir konuyu anlamak, eğlenmek, entelektüel istek, geleneksel eğitimdeki sınırlamalar olmadan öğrenme olarak belirtilmiştir. Benzer olarak Hew ve Cheung (2014) KAÇD kullanım motivasyonlarını belirli bir konuya ilgili olmak, bilgi düzeyini yükseltmek, ücretsiz kaynaklar bulmak, merak, şahsi meydan okuma ve sertifika almak olarak listelemiştir. Ek olarak, Zutshi, O'Hare ve Rodafinos (2013)'un çalışmasındaki katılımcılar, diğer katılımcıların fikir ve çalışmalarını gördükleri için heyecan duyduklarını, böylelikle profesyonel gelişmelerinin desteklendiğini belirtmişlerdir. Bazı öğrenciler için sertifika/diploma almanın güdüleyici bir etkisi olduğu belirtilmiştir (Hew ve Cheung, 2014; Kizilcec, Piech ve Schneider, 2013), fakat bu sertifikaların geleneksel öğrenme ortamlarıyla aynı kaliteye sahip olmadığı belirtilmiştir (Parr, 2013). Ayrıca, KAÇD’nin sunduğu erişim kolaylığı farklı öğrenen gruplarının ilgisini çekse de çalışmalar çoğu kullanıcının hali hazırda bir resmî diplomaya sahip olduğunu ve kullanıcıların çoğunluğunun yetişkin yaşam boyu öğrenciler olduğunu ortaya koymuştur (Yuan ve Powell, 2013; Macleod, Haywood, Woodgate, ve Akhatnai, 2015). Yayınlanan bir çalışmada da belirtildiği üzere KAÇD kullanım nedenleri kariyer gelişimi, profesyonel gelişim/sertifika edinimi, çevrimiçi öğrenme ortamlarını inceleme, yeni bilgiler edinme ve yeni insanlarla tanışma olarak belirtilmiştir (Macleod, Haywood, Woodgate, ve Akhatnai, 2015). Yukarıda belirtildiği gibi kullanıcıların daha çok ilgilerini çeken ve ihtiyaç duydukları konuları takip etmek istemeleri, sertifika almanın veya dersi tamamlamanın temel motive edici ögeler olmadığını ortaya koymaktadır.

Liu, Kang ve McKelroy'un (2015) çalışmasında 409 katılımcıya anket uygulanmış ve katılımcıların KAÇD ortamına katılma nedenleri ve bu süreçteki deneyimleri araştırılmıştır. Bu çalışmanın sonucuna göre katılımcıların amaçları bireysel ve profesyonel amaçlı bilgi edinme, ders içeriklerine erişim, gelecek meslek seçimi ve sertifika alma olarak belirlenmiştir. Deneyimleri konusunda ise yüz yüze veya çevrimiçi eğitimle karşılaştırıldığında katılımcıların yarıdan fazlası KAÇD sürecini olumlu olarak değerlendirirken (esnek öğrenme ortamı, içerik kalitesi, erişim kolaylığı ve iletişim kolaylığı), bir kısım katılımcı ise süreci olumsuz olarak (düzensiz/dağınık öğretim ortamı, geribildirim eksikliği, motivasyon eksikliği) değerlendirmiştir. Pozon-Lopez, Higueras-Castillo, Munoz-Leiva ve Liebana-Cabanillas'ın (2020) çalışmasında ise öğrenenlerin KAÇD kullanma niyetleri ve kullanma deneyimlerindeki doyum ilişkisi incelenmiştir. Bu çalışmaya göre, kullanma niyetini yordayan en önemli faktörlerin deneyimdeki doyum ve otonom motivasyon olduğu ortaya konulmuştur. Ayrıca, kullanım doyumunu belirleyen önemli faktörlerin de dersin kalitesi, kullanışlılı̆ı ve eğlendirme değeri olduğu bulunmuştur.

Üstteki çalışmalarda da bahsedildiği üzere katılımcıların KAÇD uygulamalarına katılma motivasyonları yanında yaşadıkları deneyimler de sürecin değerlendirilmesi açısından önemli bir yere sahiptir. Zutshi, O’hare ve Rodafinos (2013) çalışmalarında katılımcıların diğer öğrenenlerin çalışmalarını ve fikirlerini görme konusunda heyecanlı hissettiklerini fakat hepsinin tartışma etkinliklerine katılmadıklarını veya tamamlamadıklarını belirtmişlerdir. Hatta bazı öğrencilerin bu etkinlik ve etkileşimleri fazla yorucu buldukları vurgulanmıştır. Öğrenci bakış açısına göre diğer engellerden biri de tek başına veya bir grubun parçası olarak hissetmemek olarak belirtilmiştir (Zutshi, O’Hare ve Rodafinos, 2013). Bazı öğrencilerin bir grubun parçası gibi hissetmemelerinin nedeni grubun herkesin birbirini tanıyabileceği seviyenin çok üstüne öğrenci sayısına sahip olması olarak değerlendirilebilir. Hew ve Cheung'un (2014) derlemesine göre ise öğrenenlerin süreçte karşılaştıkları engeller: özendirici eksikliği, tartışma forumlarındaki odak konu eksikliği, konu hakkında önbilgi eksikliği, belirsiz ölçme unsurları ve beklentiler, geribildirim/yardım eksikliği ve zaman sıkıntısı olarak sıralanmıştır.

\section{KAÇD Tasarımı ve Karşılaşılan Engeller}

Öğretim tasarımı modelleri, temel anlamda öğretim teorilerinin prensiplerinin nasıl uygulanacağına dair öğreticilerin yönlendirilmesini sağlayan basamakları detaylandıran aşamalar ve süreçler bütününü ifade eder (Driscoll, 2000). 1960'lar ve sonrasında ortaya çıkan, öğretim sürecinin ve kaynaklarının düzenlenmesi ve etkinliğinin arttırılması çerçevesinde şekillenen öğretim tasarımı modellerinin (Zhu, Bonk ve Sari, 2018) bazılarının çevrimiçi öğrenme ortamları için uygun olabileceği belirlenmiştir (Branch and Dousay, 2015). Temelde bilinen ADDIE modeliyle benzer unsurlar barındıran bu tasarım süreçleri, KAÇD tasarımı ve 
uygulama aşamalarında eğitmenler açısından faydalı olabilmektedir. Temelde uygulanacak adımlar öğretim tasarımı modelleriyle çizilse de uygulanacak pedagojik yaklaşımlar KAÇD uygulamaları düşünüldüğünde iki farklı rotada değerlendirilmektedir. Bu çerçevede, CMOOC ve xMOOC olmak üzere iki farklı tür KAÇD ortaya çıkmıştır (Jacoby, 2014). cMOOC türü, bağlantıcılık (connectivism) pedagojisi dahilinde sosyal iletişim ağı ve sosyal beceriler kavramlarını benimserken, xMOOC geleneksel öğretim yöntemlerinden beslenen, öğretici tabanlı ve bireysel öğrenmeyi daha çok göz önünde bulunduran bir öğretim yaklaşımını benimsemektedir (Downes, 2012; Pilli ve Admiraal, 2016). Genelde literatürde bu kategoriler kabul görse de bazı çalışmalarda farklı unsurlar gözetilerek oluşturulan KAÇD sınıflandırmaları mevcuttur (Clark, 2013; Conole, 2014; Pilli ve Admiraal, 2016; Liyanagunawardena vd., 2019). Buna rağmen, farklı isimlerle uygulamaya konulan KAÇD'lerin büyük bir kısmının, cMOOC ve xMOOC yaklaşımlarında benimsenen pedagojik altyapıların harmanlanmasıyla ortaya çıktığı belirlenmiştir. Tasarım ve uygulama sürecinde yararlanılan süreçlerin haricinde, özellikle bu süreçte yaşanan deneyimler, bu sürecin avantajları ve karşılaşılan engeller, KAÇD çalışmalarında üzerinde durulması önemli olan konulardandır. Ancak, spesifik ortam ve içerik dahilinde farklılaşan öğretim tasarımı yaklaşımları ise yapılan çalışmalarda farklı sonuçlar elde edilmesine yol açabilmektedir. Bu nedenle, KAÇD yaratma, yönetme ve sürdürülebilirliğini sağlama sürecinin teknolojik, lojistik ve pedagojik unsurlar açısından düşünülmesi gereken bir süreç olduğu ön plana çıkmaktadır (Alario-Hoyos, Perez-Sanagustin, Cormier, Delgado-Kloos, 2014). Teknolojik unsurlar derslerin sağlanacağı teknik altyapı unsurlarını, lojistik unsurlar da bu süreçte harcanacak olan iş gücünü temsil ederken, pedagojik unsurlar KAÇD’nin bünyesinde barındırdığı çevrimiçi öğrenme ortamları ve öğrenen özellikleri farklııklarını dikkate almaları gereken bir yapıyı işaret etmektedir (Alario-Hoyos, Perez-Sanagustin, Cormier, Delgado-Kloos, 2014)

Alan yazın taramasında, KAÇD uygulamalarında karşılaşılan engeller ve bu uygulamanın sunduğu yararlar hakkında çeşitli sonuçlar olduğu görülmüştür. Yuan ve Powell (2013) bu süreçte karşılaşılan engelleri şu kelimelerle özetlemektedir: sürdürülebilirlik, kalite, pedagojik sorunlar, tamamlama ve motivasyon. Benzer olarak Milheim (2013) ve Richter ve Krishnamurthi (2014) de bu süreçte karşılaşılan engelleri şu şekilde listelemiştir: öğrenenlerin dersi tamamlama oranları, dersi yaratma ve sürdürme aşamasındaki finansal sorunlar, sertifikasyon sorunları, öğrenci performanslarının değerlendirilmesindeki geçerlilik ve güvenilirlik sorunları. Belirtilen çeşitli engeller arasında ön plana çıkan unsurlar 4 kategoride değerlendirilebilir: iletişim, pedagojik unsurlar, zaman yönetimi ve ölçme ve değerlendirme. Tasarım sürecinde düşünülen önemli unsurlardan biri iletişimi sağlamaktır. Farklı türlerde şekillenebilen iletişim unsurunun (öğrenen-öğrenen, öğrenen-öğretici, öğrenen-ortam, öğrenen-içerik) online eğitimi de kapsayacak şekilde tüm eğitim süreçleri için önemli olduğu ortaya çıkmıştır (Stracke vd. 2018). Hew ve Cheung'un (2014) literatür dahilinde derledikleri çalışmalardan çıkan sonuçlara göre, öğreticilerin tasarım sürecinde yaşadıkları 4 engel ön plana çıkmıştır: öğrenci yanıtı/ortama katılımın eksikliği, öğrenci geribildirimi eksikliği, zaman ve para sıkıntısı ve ölçme ve değerlendirme problemleri. Bu problemlerden, öğrencilerin ortamla, diğer katılımcılarla ve öğreticilerle iletişimini sağlamada problem yaşadığı belirlenmiştir.

Tasarım ve uygulama süreci pek çok unsuru içinde barındıran kompleks bir yapıyı içermektedir. Bu süreçte yararlanılan pedagojik yaklaşımlar ve öğretim sürecinin planlanması ve uygulama aşamaları pek çok zorluğu beraberinde getirmektedir. Sari, Bonk ve Zhu'nun (2020) çalışmasına göre tasarım ve uygulama sürecinde karşılaşılan önemli engeller; öğrenenlerle işbirliği, ortama dahil olmalarını sağlama için çeşitli uygulamalar geliştirme, video geliştirme süreci ve zaman kısıtlamaları olarak belirtilmiştir. Bu unsurlar özellikle dersin kalitesine yönelik algıya etkisine yönelik çalışmalarda ortaya çıkabilmektedir. Lowenthal, Snelson ve Perkins'in (2018) yaptığı çalışmada öğreticilerin motivasyonlarının, öğretim deneyimlerinin ve KAÇD uygulamasının eğitsel değerine dair görüşlerinin ortaya çıkartılması amaçlanmıştır. Bu çalışmanın sonucuna göre, ders vermeye yönelik içsel motivasyonun dışsal motivasyona göre daha ön planda olduğu, online pedagojik yaklaşımlar konusunda profesyonel deneyim kazandıkları ve KAÇD dahilinde yer alan bazı engellerin derslerin kalitesine yönelik algıya etki ettiği ortaya çıkarılmıştır. Bunun yanı sıra, tasarım sürecinde düşünülen ögelerden birisi olan dersi yarıda bırakma (dropout), özellikle tasarlanan derslerin kalitesinin düşük olduğu algısına yol açmış ancak bu yaklaşımın mantıklı bir çıkarsama olmadığı belirtilmiştir (Stracke, vd., 2018).

Ölçme ve değerlendirme konusu ise temelde çevrimiçi öğrenme sürecinde var olan endişelerin KAÇD ortamında karşılaşılan yüksek sayıda katılımcıyla beraber farklı endişelerin de beraberinde gelmesine neden olmuştur. Richter ve Krishnamurthi (2014) ve Spector (2014) temelde ölçe ve değerlendirme ile ilgili sorunu çok sayıda insanı değerlendirmenin zor olması ve uygun ve detaylı geri bildirim vermenin zorluğu ile açıklamaktadırlar.

En çok değinilen engel olan zaman yönetimi mevzusu da temelde tasarım sürecinde ve uygulama süreçlerinde karşımıza çıkmaktadır. Öğreticilerle yapılan bir diğer çalışmada, karşılaşılan en önemli engellerin pedagojik endişelerin giderilmesi, teknik problemlerin çözümlenmesi, harcanan zaman olduğu belirtilmiştir. Bu araştırmaya göre ayrıca eğitim veren kişilerin bu engellerin farkında olduğu ve temelde bu deneyimi yaşamaktan memnun oldukları ortaya çıkarılmıştır (Evans ve Myrick, 2015).

\section{YÖNTEM}

Bu çalışmanın amacı bir KAÇD ortamının tasarımı, sunumu ve kullanımındaki anahtar noktaları ve deneyimleri detaylıca ortaya koymaktır. Bu amaç ışığında, araştırma durum çalışması olarak tasarlanmıştır. Yin'in (2009) önerdiği gibi, olay (KAÇD ortamı), gerçek yaşam bağlamında (bir KAÇD ortamının tasarımı ve uygulaması süreci) özgül kullanıcılarla (KAÇD tasarım ve geliştirme grubu) incelenmiştir. Ek olarak, bu özel durumda (üniversitede bir öğretim üyesi tarafından sunulan dersi) uygulamanın detaylı bir açıklaması sunulacaktır. Dolayısıyla bu çalışma tekil durum çalışması olarak tasarlanmıştır. Bu çalışmanın araştırma soruları aşağıdaki gibidir:

1. Eğitmen ve öğrenen bakış açısıyla KAÇD kullanıcılarının deneyimleri ve görüşleri nelerdir? 
2. Bir KAÇD tasarımı ve yönetimi esnasında karşılaşılan zorluklar/engeller nelerdir?

3. Tasarım ve uygulama sürecinde karşılaşılan engeller için üretilebilecek çözümler nelerdir?

$\mathrm{Bu}$ araştırma dahilinde incelenen KAÇD ortamı, Amerika Birleşik Devletleri'nin güneydoğusunda bulunan bir devlet üniversitesinde bir profesör ve asistanları tarafından tasarlanan ve uygulanan bir KAÇD dersinin detaylı incelenmesi gerçekleştirilmiştir. Bu ders KAÇD olarak tasarlanmış olup, özellikle derslerinde sosyal medya unsurlarından faydalanmak isteyen eğitimciler hedef alınmıştır. Bu ders 2014/2015 yarıyılında tek dönem açılmış olup yaklaşık 4 hafta boyunca sunulmuştur.

\section{Katılımcılar}

Dersi tasarlayan, yöneten ve uygulayan toplam 17 kişiden (1 öğretim üyesi ve 16 araştırma görevlisi veya doktora/ylisans öğrencisi) oluşmaktadır. Amaçlı örnekleme yöntemi ile bu kişilerden katkısı ve tasarımdaki rolleri göz önünde bulundurularak, deneyimleriyle ilgili yeterli bilgi sunabilecek 10 katılımcı seçilmiştir. Bu katılımcıların herhangi bir bilgisi paylaşımayacak olup bu çalışma boyunca "eğitmen" veya "katılımcı" olarak isimlendirileceklerdir. Eğitmenlerin hepsi belirtilen üniversitede yüksek lisans veya doktora eğitimin devam ettiren veya araştırma görevlisi olarak çalışan kişilerden oluşmaktadır. Ayrıca tüm katılımcılar (öğretim üyesi de dahil olmak üzere), öğretim teknolojisi alanında çalışan veya uzmanlaşan kişilerden oluşmaktadır.

\section{Veri Toplama}

Bu çalışmanın uygulanması iki aşamada gerçekleştirilmiştir. ilk aşamada araştırmacılar etkinlikleri, materyalleri, öğrenci davranışlarını ve yönetimsel sorunları inceleyebilmek için KAÇD ortamını dersin baş asistanı ile birlikte gözlemlemiştir. Bu süreçte ayrıca verilen ders ile ilgili veri dosyaları da toplanmıştır. Bu dosyalarda genelde dersi alan katılımcılarla ilgili bilgiler yer almakta olup bu bilgiler çalışmanın odak noktasında yer almasa da sonuçların yorumlanması açısından faydalı olmuştur. İkinci aşamada ise katılımcılarla görüşmeler yapılmıştır. Yarı yapılandırılmış görüşme soruları KAÇD ortamını yaratma, yönetme ve uygulama süreçlerini ve deneyimlerini açığa çıkarmak için hazırlanmıştır. Her bir katılımcı ile görüşme yaklaşık 45-60 dakika sürmüş olup, bu görüşmeler yüz yüze veya çevrimiçi görüşme tekniğiyle gerçekleştirilmiştir.

\section{Veri Analizi}

Katılımcılardan toplanan verilerin analizi için NVivo programı kullanılmış olup, nitel analiz yöntemleri takip edilmiştir. Önerildiği gibi tüm görüşme dosyaları transkript edilip öncelikle kodlara ayrılmış, sonrasında da temalar oluşturulmuştur (Creswell, 2012). Oluşturulan kodlar ve temalar alandan başka bir uzman tarafından da kontrol edilmiştir. Ayrıca görüşme ve gözlem verileri birleştirilmiş ve sonuçlar, bu kodlar ve temalar çerçevesinde araştırma sorularına cevap olacak şekilde yorumlanmıştır.

\section{Sınırlılıklar}

Bu çalışma, tekli durum çalışması olarak tasarlanmış ve üretilen tek bir ders üzerinden gözlem yapılmıştır. Ayrıca bu çalışma ve sonuçları, bu dersi tasarlayan katılımcıların deneyimleri ve gözlemleriyle sınırlıdır

\section{Ders Ortam}

KAÇD öğrencilerin öğrenme işlevlerini sosyal medya kullanarak desteklemek isteyen eğitimciler için bir çevrimiçi öğrenme ortamı olarak tasarlanmıştır. Proje 4 hafta Blackboard isimli ders yönetim ortamı üzerinden sunulmuştur ve her hafta sosyal medyanın farklı bileşenlerini öğretmek üzere tasarlanmıştır (Hafta 1/oluşturma, Hafta 2/sosyal medya dersleri, Hafta 3/kişisel öğrenme ağları, Hafta 4/mahremiyet ve etik). Her hafta farklı bir modül olarak tanımlanmış ve bu modüller konular bazında ayrıştırılmıştır. Ders etkinlikleri ve adımları Şekil 1'de sunulmuştur. Derse 4 hafta boyunca, farklı yerlerden toplamda 600 kişi kaydolup katılmıştır.

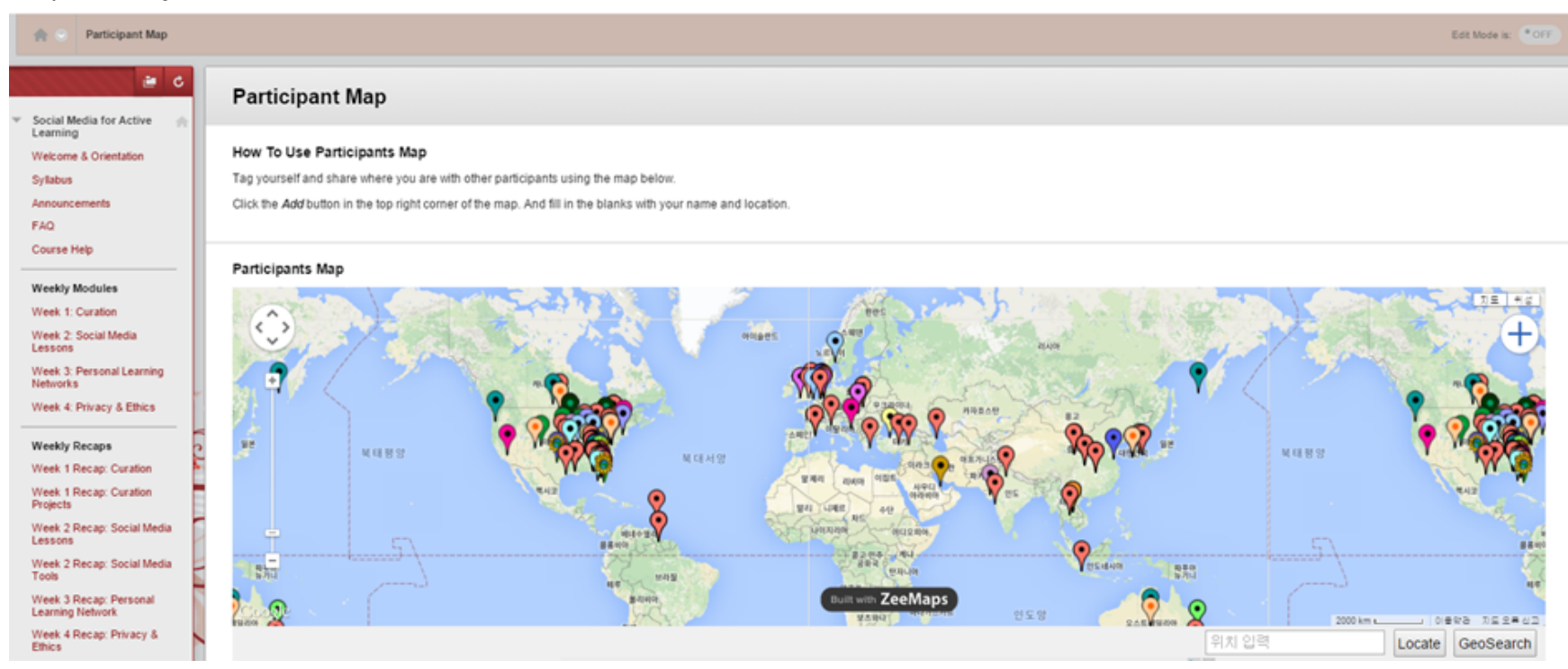

Şekil 1. Derse kaydolan katılımcı haritası 


\section{Tasarım Süreci}

Tasarım sürecindeki etkinlikler 3 aşamada planlanmıştır (Şekil 2). Ilk aşamada öğretim üyesi ve lider araştırma görevlisi konu, içerik ve uygulanması planlanan aktiviteler hakkında araştırma yapmışlardır. Bu araştırma sonucunda derlenen bilgilerle dersi tasarlayan diğer eğitmenlere bir kılavuz hazırlamışlardır. íkinci aşamada, öğretim üyesi hariç 16 kişiden oluşan eğitmen grubu dörderli gruplara ayrılmış ve her grup her bir haftadan sorumlu eğitmenler olarak atanmıştır. Hazırlanan kılavuzlar da her bir grubun kendi modülünde tasarlayacağı pedagojik unsurlara (içerik, ödevler, iletişim unsurları, ölçme ve değerlendirme, kaynaklar) yönelik sunulmuştur. Buna ek olarak, her bir eğitmene dersin uygulanma sürecinde yapacakları görev tanımlamaları da verilmiştir. Son aşamada ise, her bir grup kendi haftaları için hazırladıkları tasarımları sunmuş ve bu haftalar için ortak bir tasarım fikrinde uzlaşıımıştır.

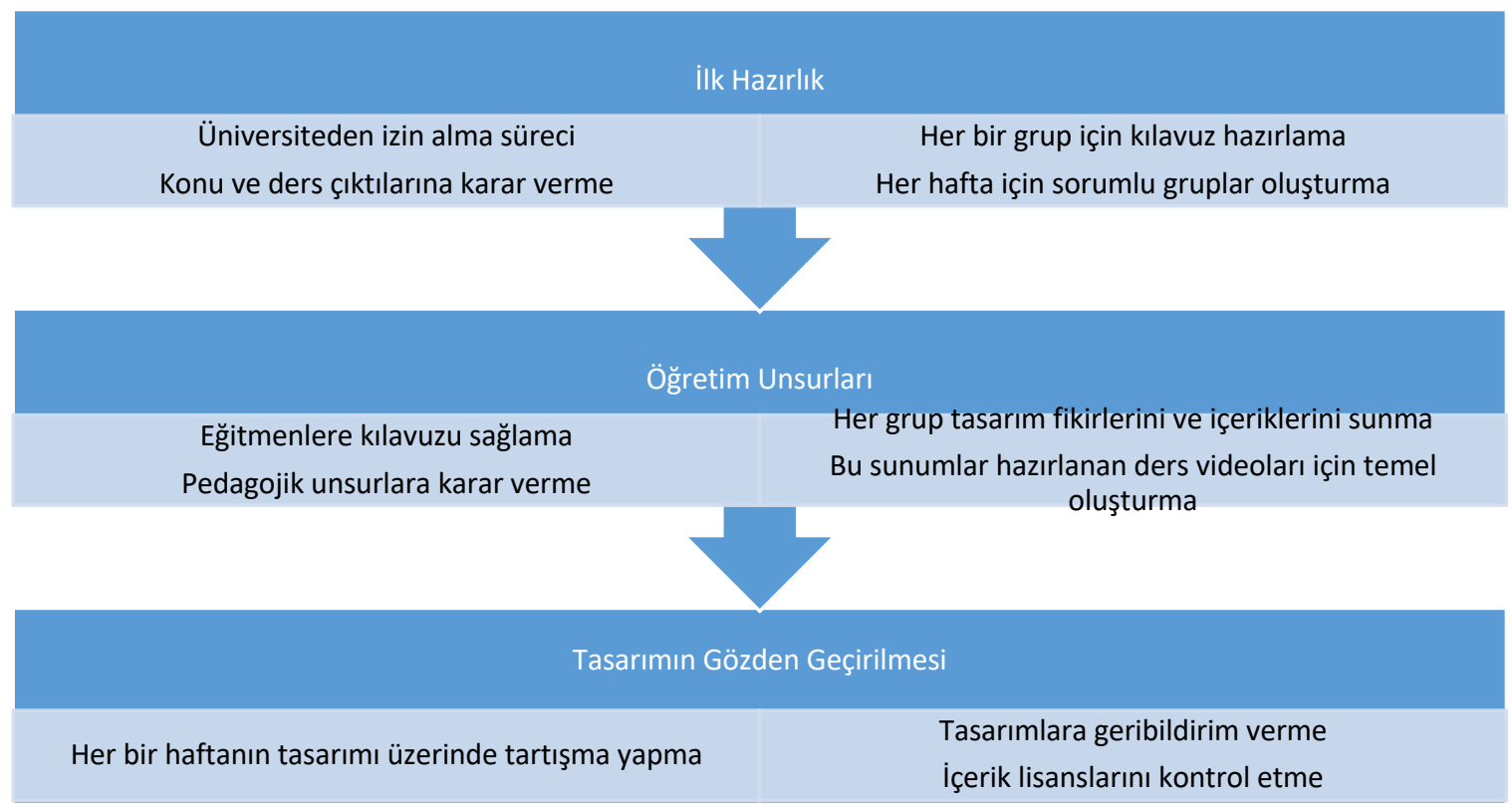

\section{Şekil 2. KAÇD tasarım süreci}

\section{Uygulama Süreci}

4 haftalık mini bir açık ders olarak tanımlanan SMOOC, katılımcıların 4 haftalık süreçte her hafta için verilen uygulamalar ve ödevleri tamamlamaları dahilinde rozet kazanmalarını sağlayan bir sistem olarak tasarlanmıştır (Şekil 3).

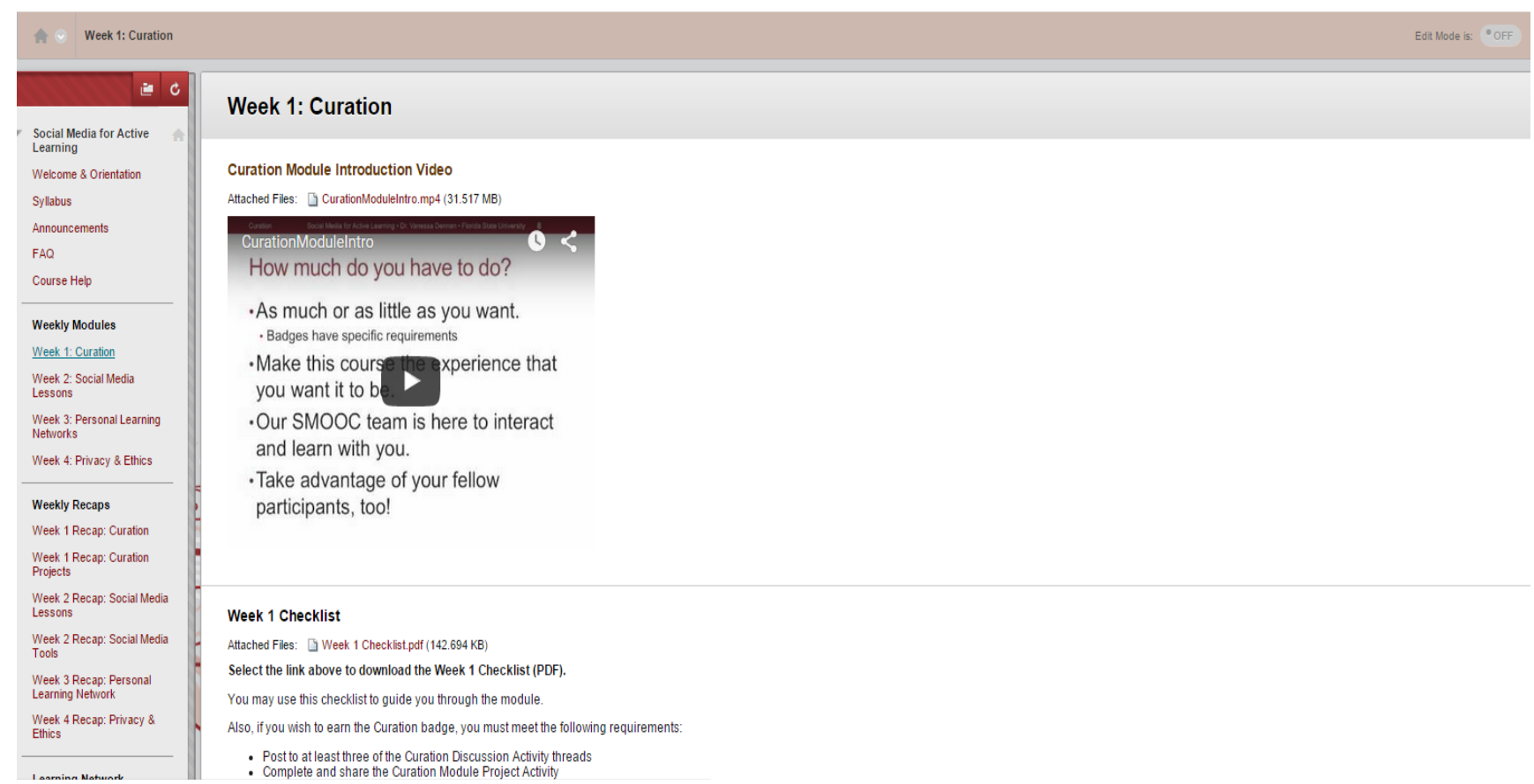

\section{Şekil 3. KAÇD ders ortamı ve haftalık etkinlik örneği}

Uygulama sürecinde ise Resim 4'te görüldüğü üzere farklı uygulamalar ve etkinlikler karşımıza çıkmaktadır. Katılımcılar derse katıldığında ilk olarak derse ısınma etkinlikleri ve kısaca dersi tanıtan tanıtım videosuyla karşılaşmaktadırlar. Onun haricindeki tüm uygulamalar tamamen katılımcıların isteğine göre kullanılabilecek şekilde düzenlenmiştir. Haftalar birbirini takip eden ders 
içerikleri yerine sosyal medya kullanımının farklı unsurlarını içeren birbirinden farklı modüller olarak düşünülmüştür. Bu nedenle katılımcılar, ihtiyaçlarına göre haftalık modülleri takip edebilir ve ilgi duymadıkları modülleri geçebilmektedirler. Her bir modülde yer alan etkinlikler ise: konuyla ilgili video, akademik kaynaklar, sunum veya ek videolar ve ölçme değerlendirme şeklindedir. Haftalık verilen içerikle ilgili kaynakların yanında öğrencilerin değerlendirilmesi için 3 farklı değerlendirme yöntemi kullanılmıştır: tartışma panosu, çoktan seçmeli sınavlar ve projeler. Tartışma panosu her haftanın sonunda verilen 3 soruya yanıt verilmesi şeklinde gerçekleştirilmiştir. Ayrıca haftalık olarak farklı dilde tartışma grupları da oluşturulmuş (İngilizce, İspanyolca, Korece ve Çince) ve katılımcıların iletişimini arttırması amaçlanmıştır. Not vermekten ziyade geçme/kalma sistemi üzerinden puanlandırma yapılmıştır. Sınavlar haftalık modülde otomatik notlandırılan bir sistem üzerinden değerlendirilmiştir. Her bir haftanın sonunda verilen projelerin notlandıııması konusunda sadece başta rozet kazanmak istediğini beyan eden katılımcıların projeleri değerlendirilmeye alınmıştır.

Bu süreçte katılımcıların derse dahil olmalarını ve iletişimi arttırmak amacıyla da haftalık konuyla alakalı bir konuk konuşmacıyla gerçekleştirilen webinar uygulaması, tartışma panoları ve sosyal medya platformları (Facebook ve Twitter) oluşturulmuştur. Özellikle sosyal medya platformları tartışma panolarına benzer ama daha gayri resmî şekilde kullanılmış olup, modülden sorumlu eğitmenler tarafından öğrencilere ilgilerini arttırmak için sorular sorulmuştur.

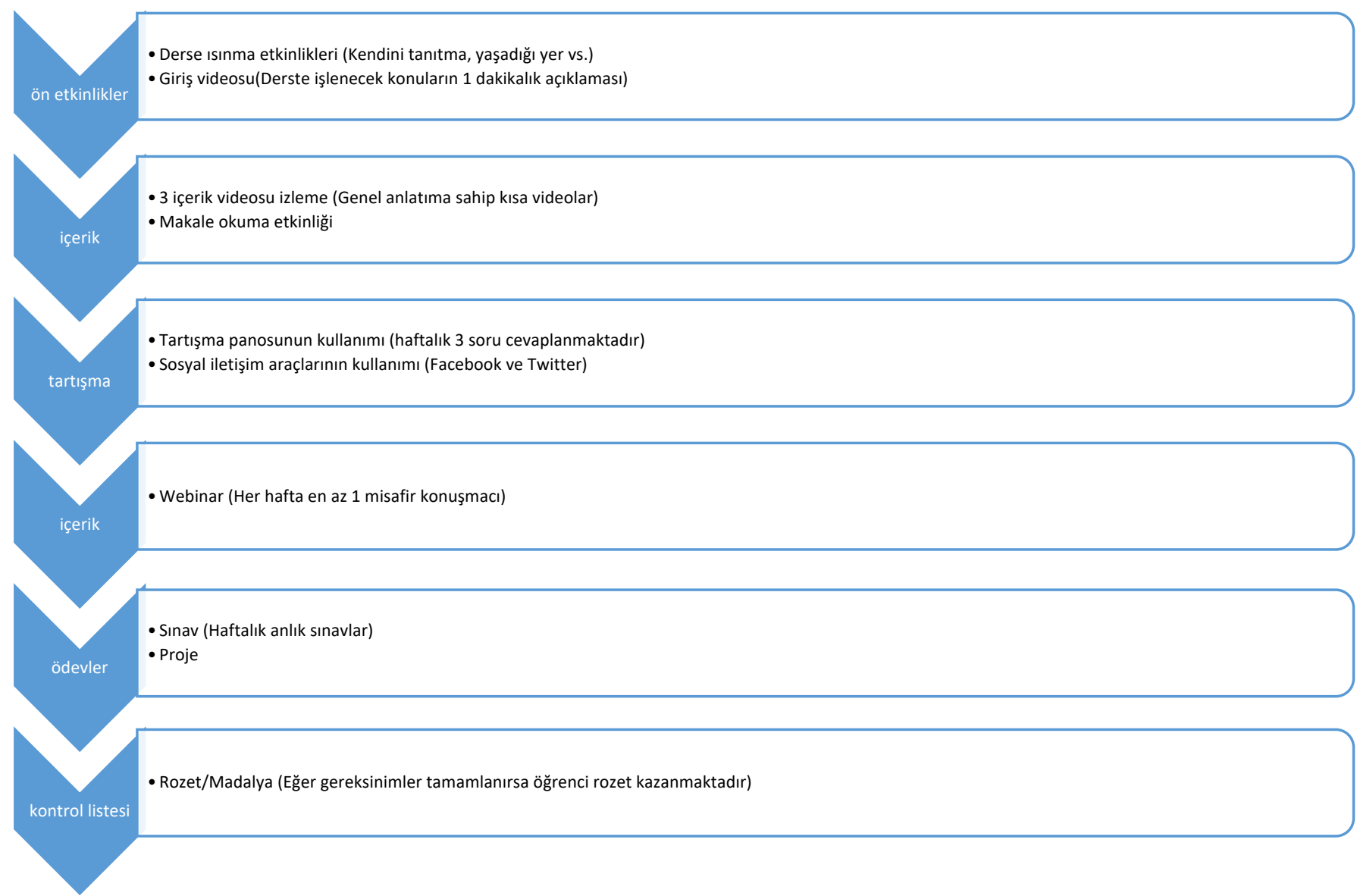

\section{Şekil 4. KAÇD ortamındaki haftalık uygulamalar}

Uygulama sürecinin yönetilmesinde de eğitmenlerin sorumluluğunda olan bazı görev dağılımları yapılmıştır. Kendi modüllerini tasarlama sürecinden sorumlu olmalarının yanı sıra, her bir eğitmen farklı uygulamaların yürütülmesinden sorumlu hale getirilmiştir (5 eğitmen tartışma ortamındaki yazılanların değerlendirmesinden sorumluyken, 3 eğitmen sosyal medya yazışmalarını yönetmekle görevlendirilmiştir). Bu şekilde, takım çalışması ile tasarım ve uygulama süreçleri ve dersin işleyişindeki düzen sağlanmaya çalışılmıştır.

\section{BULGULAR}

Görüşmelerin analizi sonucunda temalar ve alt temalar ortaya çıkmıştır (Tablo 1). Görüşmede katılımcılara KAÇD ile ilgili deneyimlerine yönelik sorular sorulmuş, eğer söz konusu projeden önce KAÇD deneyimleri varsa (eğitmen veya öğrenen olarak) açıklamaları istenmiştir. Katılımcıların tamamının önceden KAÇD deneyimi olmuş; bunlardan ikisi eğitmen, sekizi öğrenci olarak bir KAÇD ortamına dahil olmuştur. Çoğunlukla kullanılan platformların Coursera ve edX olduğu belirtilmiştir. 
Tablo 1. Nitel analiz sonuçları, temalar, kodlar

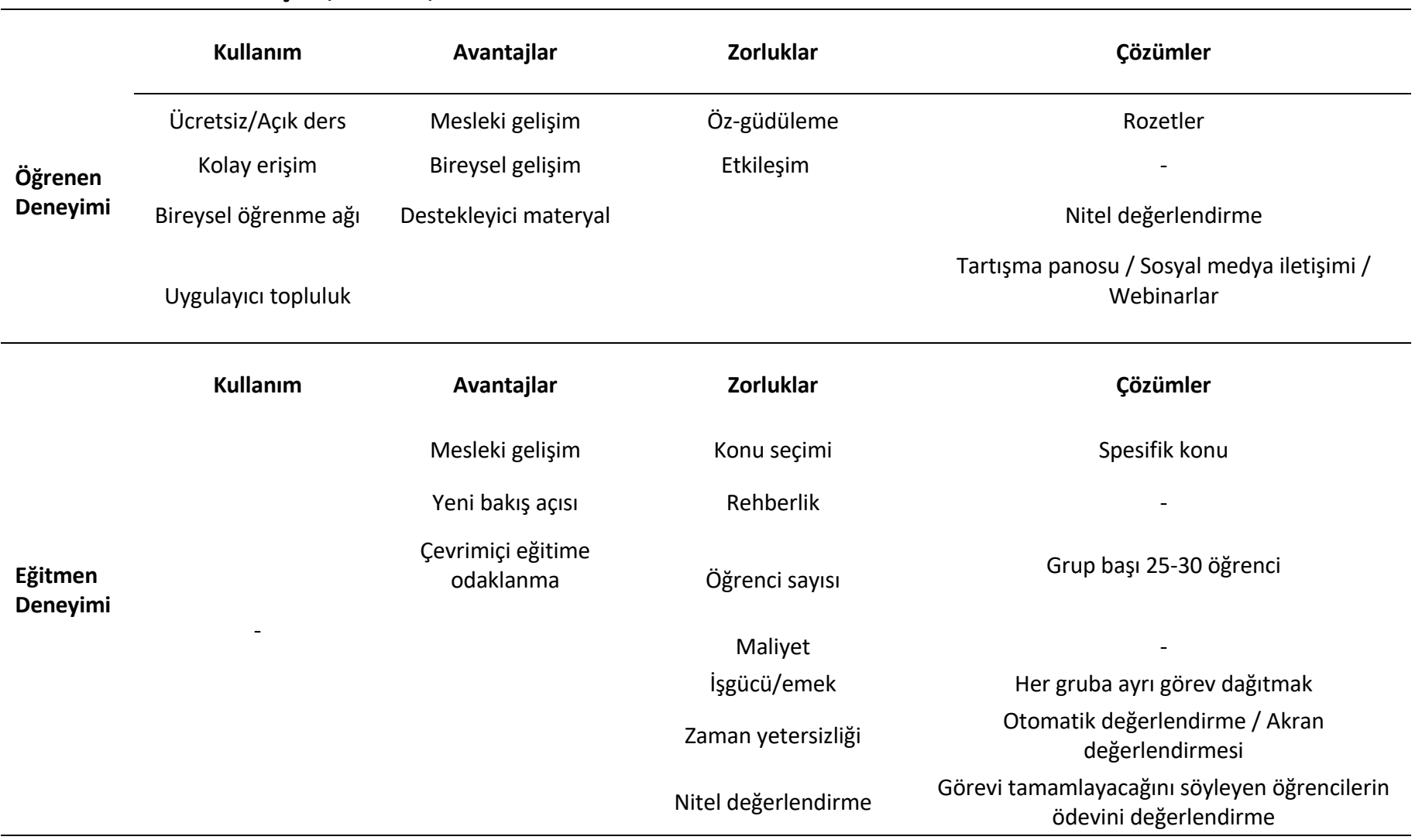

\section{Öğrenen Deneyimi}

\section{KAÇD Ortamlarını Kullanma Sebepleri}

Katılımcılar bu proje öncesinde öğrenen olarak katıldıkları KAÇD ortamlarına katılma nedenlerini; merak, ilgilendikleri konular hakkında bilgi sahibi olmak, destek materyali bulmak, ücretsiz ders veya kaynaklar bulmak, profesyonel/mesleki gelişimi artırmak ve bireysel gelişim olarak belirtmiştir. Katılımcıların çoğunluğu KAÇD ortamlarını kullanmaya ortamı keşfetmek ve ortamda neler olduğunu merak ettikleri için başladıklarını belirtmişlerdir. Ek olarak, bu ortamları kendi derslerine yardımcı materyaller bulmak için;

"KAÇD benim için destek materyal, yardımcı demek. Belirli bir konuda kaynakları almak için tek seferlik alışveriş yaptığım bir mağaza gibi."

öğretmeni oldukları dersler konusunda yeni fikirler edinerek mesleki gelişim sağlamak için;

"Lisans dersi veriyorum ve verdiğim derslere çok benzer derslere bakıp yeni fikirler ediniyorum."

ve merak ettikleri konular hakkında bilgi temin etmek için kullandıklarını belirtmişlerdir.

"Her zaman yeni şeyler öğrenmeyi sevmişimdir. Illk olarak ilgimi çeken bir ders seçiyorum. Tabi ki mühendislik dersleri gibi dersleri seçmiyorum. O konuları bilmediğim için. içeriği becerilerimi geliştirmeme yardım eden dersleri seçmek istiyorum."

\section{Öğrenen Deneyimine Göre KAÇD Avantajları}

Katılımcılar, daha önceki KAÇD öğrenen deneyimlerindeki avantajlardan bahsetmişlerdir. Bu avantajlardan en yaygın bahsedileni, öğrenenden beklenen bir yükümlülük olmaması ve ücretsiz kaynağa kolayca ulaşma imkânı olarak ortaya çıkmıştır.

“Cebir gibi bir ders mesela, ben üniversite 1. Sınıf öğrencisiyken KAÇD’ler olsaydı, üniversitede para verip dersi almadan önce KAÇD'de alırdım. Çünkü matematikle aram iyi değil ve birkaç kez cebir dersi almak zorunda kaldım. Ve birkaç kez ücretini ödemiş oldum. KAÇD’ler olsaydı hiçbir sonuca katlanmadan dersi alırdım. Oradan tekrar tekrar alır ve öğrenirdim. Öğrendikten sonra üniversitede ücretiyle dersi alıp dersi geçerdim.”

"Bence destekleyici ve kritik bir şey... Nüfusu kalabalık ülkeleri için, fiziksel olarak derse katılamayanların olduğu yerlerde, KAÇD gibi çevrimiçi ortamlardan daha fazla yararlanabilirler."

Katılımcılardan bazıları öğrencilerin uygulayıcı topluluklarını ve kişisel öğrenme ağlarını genişletmeleri için KAÇD ortamlarındaki iletişimin önemini vurgulamıştır. Sosyal iletişim, öğrenen deneyimlerindeki avantajlardan bir diğeri olarak öne sürülmektedir.

"Benim için asıl soru 'KAÇD bana Wikipedia'nın sunmadığı ne sunuyor. Bence sunduğu wikinin öğrencilere sağlamadığı uygulayıcı topluluk potansiyelini sunmasıdır."

“Benzer ilgiye sahip kişileri bulabiliyorduk. Bu KAÇD’de de bazı öğrencilerin ismini hatırladım ve sosyal medya hesaplarını paylaştılar. Ve onlarla bağlantı kurdum yani bireysel öğrenme ağımızı genişletmek mümkün." 
Ek olarak bir katılımc diğer insanlarla bir bağ kurmanın ve ilişki kurabilmenin önemini vurgulamıştır. Bu katılımcı KAÇD’leri etkileşim özelliği için tercih ettiğini belirtmiştir.

"Bir KAÇD tamamlarsanız sonunda aktif olan bazı akranlarınızı bulmuş oluyorsunuz. Yani düşününce bir KAÇD dersini ve açık ders kaynaklarını tamamladığınızda, sonuç olarak elinize geçen tamamen farklı. KAÇD’de başarılı olursam diğer açık ortamlar gibi bir sürü şey öğrenirim. Fakat aynı zamanda diğer başarılı öğrencilerle ilişki de kurmuş olurum."

\section{Öğrenen Deneyimi Esnasında Karşılaşılan Zorluklar}

Öğrenen bakış açısını içeren son bölüm bu deneyim esnasında karşılaşılan zorlukları içermektedir. Katılımcılardan ikisi herhangi bir KAÇD ortamına katılmadan önce bu dersin ihtiyaçlarını karşılayıp karşılamayacağına karar vermenin ve bu süreçte harcanan zamanın engel yarattığından bahsetmişlerdir. Ek olarak bir katılımcı dersi bitirmek için motivasyonunu yüksek tutmanın zorluğundan söz etmiştir.

“Bence öğrenci tarafındaki temel sorun motivasyon; öz-güdülemeyi tanımadığın, konuya ilgisi olan, senin kadar konuya senin kadar odaklanmamış veya bambaşka bir deneyime odaklı rastgele insanlarla birlikte dersi tamamlayacak kadar sürdürebilmek."

Yapılan görüşmelerde, katılımcılardan özellikle KAÇD’lerdeki ve Açık Ders Kaynaklarındaki kendi kullanıcı özelliklerini tanımlamaları istenmiştir. Katılımcıların çoğunluğu kullanıcı profillerini "pusucu" olarak nitelemiş ve sadece ortamda gezinip kaynak ve ödev bulmak; tartışmaları okumak için kullandıklarını belirtmiştir. Bu katılımcılar, dersin gereksinimlerini hiç tamamlamadıklarını fakat ihtiyaç duydukları bilgi ve kaynakları seçip aldıklarını söylemişlerdir.

"Aslında birden fazla KAÇD’ye kaydoldum ama hepsini tamamlamadım. Bir çeşit pusucuydum, neyse yani diğer KAÇD'lerdeki platform ve derslerin yapısına oldukça aşinaydım."

"(KAÇD ortamında) öğrenciydim ve aslında birkaç KAÇD’yi de keşfettim fakat hiçbirini tamamlamadım, etkinliklerin hiçbirini yapmadım. Sadece birkaçını keşfettim özellikle biz bu dersi tasarlamadan bir yıl önce"

“Başka birkaç KAÇD'de bir anlamda pusucu oldum. Zaten canlı webinar dersleri de yoktu. Yani şöyle düşündüm 'tamam bu kaynaklardan yararlanabileceğin, modülleri inceleyebileceğin düzenli bir internet sitesi ama kendi değerlendirme mi de yapmayacağım"'

Başka bir katılımcı ücretsiz erişim özelliği nedeniyle kendini açık ders malzemeleri/açık eğitim kaynaklarını kullanmaya daha eğilimli gördüğünü belirtmiştir.

“Açık eğitim kaynaklarını bir öğrenci olarak kullanıyorum zaten. Yani muhtemelen açık eğitim kaynaklarını ve internetteki kaynakları KAÇD’lerden daha fazla kullanırdım çünkü bir tane daha teslim tarihini elimdekilere ekleyemem. Fakat bence KAÇD'ler açık eğitim kaynaklarından daha fazla şey sunuyor."

Bazı kullanıcılar KAÇD’lerin yorucu/bunaltıcı özelliklerinde de bahsetmiştir. Özellikle tartışma panosundaki gönderileri takip ederken ve dersin gereksinimlerini (videolar, ödevler, testler vs.) tamamlamaya çalışırken bu sürecin fazla yorucu olabildiğini belirtmiştir.

“Deneyimime göre sanırım KAÇD’lerde pusuda (sadece kaynak kullanan) olmamın sebebi sanırım tartışmaların yorucu olmasıdır."

iki katılımcı ise, KAÇD’lerde karşılaştıkları zorluklardan biri olarak kullanıcıların ve öğretmenlerin etkileşiminin kısıtlı olması olarak vurgulamıştır.

“KAÇD’de biz öğrencilere soru sorabiliyoruz ama onlar bize soramıyor... Okul ortamında bile öğretmenlerle öğrenci arasında gerçek bir ilişki inşa etmek zor. Yani bir bağ kurmak istiyorsan daha fazla iletişime geçmelisin, çok daha fazla etkileşimin olmalı. Biz (KAÇD’lerde) bu konuda çok daha farklı bir çaba harcamalıyız çünkü öğrenciler bu konuyu önemsiyor."

Öte yandan bazı kullanıcılar tartışmaları ve webinarları takip etmenin diğer kişilerin içerik hakkında neler söylediğini öğrenmek açısından yararlı olduğunu söylemektedir.

"Mesleki gelişim açısından, evet bu konuda uzman olmayabilirim ama en azından bir KAÇD dersine gidip insanların neler söylediğini görürüm. Farklı bir görüşüm olsa bile olumlu ve olumsuz yanlarını görüp alandaki eğilimlerin neler olduğunu görmek açısından etkileyici. Kısa bir göz atma olsa da tartışmaları okuduğumda ve webinarlara canlı katılmamış olsam da sonradan izlediğimde ne olup bittiğini görmüş oluyorum."

Ek olarak belirtilen zorluklar bazı derslerde sağlanmayan sertifika veya diplomalar ve intihal problemi olduğunu belirtmişlerdir. Temelde bu iki unsur zorluktan ziyade KAÇD'lerle ilgili endişeler olarak değerlendirilebilir.

“Olumsuz tarafını düşündüğümde eğer bir KAÇD ortamındaki dersi bitirirsem ve sertifika verseler bile bir üniversitenin kendisince onaylı olmayacak. Ve diploma almak gibi de değil.

"KAÇDler için olumsuz yanlardan biri de intihal olabilir bence. Sonuçta dersi kimin tamamladığını bile bilmiyorsun, insanı da tanımıyorsun. Çevrimiçi dersimiz ... Üniversitesi tarafından sunuluyor. Ekrana intihalle ilgili uyarılar yolluyor veya intihal kontrol programıyla kontrol etmek için araçlar kullanıyorsun ama bazı KAÇD dersleri için bunu yapmak çok zor." 
Sonuç olarak öğrenen perspektifinden yaşanan zorluklarda ortaya çıkan en temel unsur öz-güdülenme ve kısıtlı iletişim olduğu ortaya çıkmıştır. Ancak, dersi sürdürebilmedeki bireysel motivasyonu sağlamak ve dersle etkileşimi sağlamak öğrenenler açısından zorluk olarak tanımlansa da bu araştırmaya katılanların çoğunun öğrenen profilinin ihtiyacı kadar bilgiyi almaya eğilimli olan ve genellikle ortamdaki iletişim süreçlerini takip eden bir yaklaşımda olduğu belirlenmiştir. Bu noktada, etkileşim sağlanan ortamlardaki iletişimin düzenlenmesi ve yönetilmesi dahilinde iletişimin kalitesinin arttırılması unsuru ön plana çıkmaktadır.

Öğrenen deneyimi açısından değerlendirildiğinde, katılımcıların bu çalışmadan önceki deneyimleri sorulmuş ve değerlendirilmiştir. Öğrenen açısından KAÇD deneyimlerinin genellikle olumlu ve faydalı olduğundan bahsedilmiş ve özellikle katılımcı profilleri düşünüldüğünde KAÇD’lerin mesleki gelişimlerini destekleme konusunda faydalı olduğu görüşünde birleşmişlerdir. Öğrenen deneyimi açısından KAÇD ortamlarının ücretsiz, esnek ve farklı bilgiler sunan ve geniş kitlelerle iletişim sağlayabilecek ortamlar sunması bu dersleri kullanmalarında en önemli nedenler olarak değerlendirilirken, bu iletişimin kalitesi ve bireysel motivasyonu sağlama unsurları ise bu süreçteki zorluklar olarak belirtilmişlerdir.

\section{Eğitmen Deneyimi}

\section{KAÇD Ortamı Tasarlamanın Avantajları}

Katılımcıların tasarladıkları KAÇD dersine yönelik tutumlarını olumlu olarak değerlendirmişlerdir. Böyle bir projeye dahil olmaktan memnun olduklarını çünkü bu projenin, çevrimiçi öğrenme deneyimlerini artırıp mesleki yönden tasarımcı/geliştirici taraflarını geliştirdiğini belirtmişlerdir. Ayrıca katılımcılar fırsatları olursa başka bir çevrimiçi öğrenme projesinde yer alma konusunda hevesli olduklarını belirtmişlerdir.

“Çok eğlenceli ve havalı bir deneyimdi. Bence öğretim teknolojileri bölümündeki lisansüstü öğrencilerin sadece tasarım açısından değil aynı zamanda içeriği sunma ve öğrencilerle etkileşim açısından da çoğunun yararlanacağı bir projeydi. Bu şekilde geriye çekilip öğrenci rolünden çıkarak, tasarımcı rolüyle diğer öğrencilerin içerikle nasıl bir etkileşime girdiğini görmek açısından da bir şans sunuyordu."

"Bence çok iyiydi çünkü farklı bakış açılarıyla görme imkanına sahiptim. Konu uzmanlığından, öğretim asistanlığına kadar... Yani meslek olarak öğretim tasarımı yapıyorum ama bu tasarım konusunda çok iyiydi. Çünkü bunu tasarlıyoruz ve yüzlerce kişiye ulaşıyor."

Katılımcıların çoğu KAÇD’yi çevrimiçi öğrenme ortamlarına yeni fikirler ve görüşler getirmeyi sağlayan bir uygulama olarak gördüklerini belirtmişlerdir. Ek olarak, mesleki bilgilerini geliştirdiği ve bireysel öğrenimlerini desteklediği için mutlu olduklarını belirtmişlerdir.

"Umarım daha fazla insanın Açık Eğitim Kaynakları konusunda farkında olmasını sağlarlar. Böylece insanlar Internet'ten iyi öğrenme materyallerini bulup kendilerine rehber olabilirler."

"KAÇD olgusu çevrimiçi öğrenmenin ne olduğu, iyi değerlendirmenin biçimi, yükseköğretimin ne olduğu, yükseköğretimin önündeki engeller, ehliyet konusunda nelere değer verilmesi gerektiği gibi konularda ilginç tartışmalar yarattı. Umarım bunlar devam eder çünkü bence bunlar değer katan tartışmalar."

\section{Tasarım ve Uygulama Sürecindeki Deneyimler}

Katılımcıların her biri KAÇD ortamlarındaki eğitmen deneyiminde öğrenen deneyimlerinden farklı zorluklarla karşılaştıklarını belirtmişlerdir. Dersi tasarlarken ve uygularken ortaya çıkan zorluklar 3 ana bileşenden oluşmaktadır: tasarım, yönetim ve değerlendirme.

\section{Tasarım}

Katılımcılar tasarım sürecindeki zorlukları şöyle tanımlamıştır: sınırlı zamanda oldukça geniş içeriği olan bir konu seçmek, öğrencilerle paylaşılabilecek ücretsiz kaynak temin etmek, öğrencilere açık/net rehberlik sunmak ve mensubu olunan kurumdan izin almak. Katılımcılardan biri konuya karar verme sürecindeki zorluktan aşağıdaki şekilde bahsetmiştir:

"Bence ilk yapılması gereken ihtiyacı karşılayan, sınırlı zamanda yönetilmeyecek kadar geniş olmayan bir konuya karar vermektir. Çünkü öğrencilerin dikkatini uzun süre ve aralıklarla ayakta tutmak oldukça zordur. 1 ay uzunluğunda bir derse birçok insan kaydolup dersi tamamlayabilir. O yüzden konuyu/içeriği seçmek inşa etmeye başlamadan önce yapılacak en önemli iş olabilir."

Konu haricinde yaşanan zorluklardan bir diğeri ise hedef kitlenin profilindeki belirsizlik ve bu süreçte katılımcılara sağlanan destek ve rehberliğin dikkatli düşünülmesi gerektiği olduğu belirtilmektedir.

"Ders açık, herkes dersi alabilir. Herkes. Yani tamamen farklı geçmiş deneyimlere sahip öğrenciler olabilir. Mesela eğer yüksek lisans seviyesinde bir ders geliştiriyorsanız, öğrenci demografisinin ne olduğunu kısmen bilirsiniz. KAÇD tasarlarken bu konuda hiçbir bilginiz olmuyor. Dolayısıyla sadece basit ve düzenli olmaya çalışıyorsunuz.

Tasarım sürecindeki en temel zorluklar katılımcı sayısının fazlalığı ve bu katılımcıların önbilgileri ve profillerindeki değişen unsurlardır. Farklı özelliklere sahip katılımcılara yönelik belirlenecek konu, içerik ve rehberlik, eğitmenleri en çok zorlayan unsurlar olarak ortaya çıkmıştır. Tasarım sürecinde diğer pedagojik unsurlara (ölçme değerlendirmenin nasıl yapılacağı, ders anlatım metotları) da değinilmiş ancak bunlar zorluk olarak ifade edilmemiştir. 


\section{Yönetim}

Katılımcılar özellikle uygulama esnasında karşılaştıkları zorlukları teknik sorunlara hızlı çözümler üretmek, kontrol etmek için çok fazla öğrencinin olması (600'ün üstünde), katılımcıların önbilgilerinin bilinmiyor oluşu, dil çeşitliliğinin etkileşimi zorlaştırması, öğrencilerin ilgisini ders boyunca sürdürmenin zorluğu ve bütçe temini olarak belirtmişlerdir. Katılımcı sayısı konusunda ise eğitmenlerden birinin yorumu aşağıdaki şekildedir:

"Öte yandan çok fazla insan var. Kontrol etmesi çok zor, neyin yanlış gittiğini bile bilemiyorsun."

Yönetim sürecinde yaşanan diğer önemli zorluk ise, bu süreçte harcanan emek ve bu emeğin karşılığı olarak sağlanabilecek mali sürecin bu formattaki bireysel deneyimlerde doğru çalışması ve sürdürülebilir olması konusunda yaşanabilecek zorluklar olarak belirtilmiştir. Özellikle büyük ölçekli iş modellerinde bu döngü sağlanabiliyorken, mali desteksiz deneyimlerde bu sürecin devamlılığının sağlanması konusunda problem olabileceği belirtilmiştir.

"Maliyete baktığımızda... Coursera çok fazla üniversite için KAÇD sunan bir şirket. Finanse etme kısmını nasıl sağlıyorlar bilmiyorum yani onlar bir iş modeli... Sanırım başlangıçta onlar da bundan nasıl para kazanacaklarını bilmiyorlardır."

"Bence bu açık platformları kullanma ve bu modeli eğitim kurumlarına uygulayıp halkın geneline yayma fikriyle ilgili büyük bir heyecan var. Fakat işe girince değerlendirmeyle ilgili ve birilerinin bunu finanse etmesiyle ilgili sorunların içine anında giriyoruz. Bunun bir maliyeti var. Elinizde bütün bir çalışan gönüllü ağı olabilir ama bu gönüllü ağını ayakta ve çalışır tutmanız da gerekiyor. Ve her zaman o kadar düzgünce çalışmıyor."

Karşılaşılan bu zorlukların yanında katılımcılar özellikle öğrenenlerle etkileşim ve motivasyon konusunda bir zorluktan bahsetmemişlerdir. Bu noktada daha önceki deneyimlerine dayanarak uyguladıkları stratejilerin etkili olduğu söylenebilir. Etkileşim bağlamında, dersi öğretim üyesi ve takımı dersi öğrencilerin birbirleriyle etkileşimini sağlamaya yönelik tasarlamışlardır. Öğrencilerin ve ders asistanlarının tartışma panosunu konuyla ilgili iletişime geçmek için yoğun olarak kullandıkları ortaya konmuştur. Ek olarak, haftalık webinarlar öğrencilerle yüz yüze etkileşimi sağlamıştır. Bu webinarlar birincil olarak ders vermek için tasarlanmamıştır. Tartışmaları derinleştirmek ve haftanın konularını gözden geçirmek için tasarlanmıştır. Ayrıca sosyal medya hesapları öğrencilerin daha rahat ve gayrı resmî şekilde ders asistanlarına ulaşabilmeleri için sunulmuştur. Öğrenciler kafalarına takılan soruları sosyal medya aracılığıyla ders asistanlarına sorabilmekte ve tartışmak istedikleri fikirlerini Twitter üzerinden yazabilmektedirler. Motivasyonu canlı tutmak için haftadan sorumlu asistanlar konuyla ilintili gönderiler paylaşmakta ve alakalı web bağlantıları sunmaktadır. Öğrencilerin motivasyonunu artırmak için ise belirli görev ve ödevleri tamamlayanlara rozetler verilmektedir. Ayrıca, içeriği iyi/ faydalı tasarlayarak, derse belli sınırlar çizerek, belirli bir konuyu odağa yerleştirerek, ders ihtiyaçlarını belirleyerek öğrencilerin konuyu rahat öğrenmeleri ve motivasyonlarının üst seviyede kalması hedeflenmiştir.

“Twitter ve Facebook'ta sürekli bir hareketlilik yoktu. Tabi çok çok fazla öğrencimiz de yoktu... Yine de etkileşimde bulunan insanlar vardı."

Katılımcılar çalışmadaki KAÇD ortamında da ders bırakma oranlarının beklendiği gibi yüksek olduğunu fakat bu konuda endişeli olmadıklarını belirtmişlerdir. Bunun nedeni hepsinin öğrencilerin çevrimiçi öğrenme ortamlarındaki davranışlarına ve alışkanlıklarına aşina olmaları gösterilebilir.

“Öğrenciler videolarımızı izlediler ama (birçoğu) ödevleri olan gönderi yazma kısmını yapmadılar. Ama bu bir şey öğrenmedikleri anlamına gelmez. Zaten videolardan öğrenmeleri gerekeni öğrendiler. Ama çoğunlukla pusucu olarak davrandılar. Tartışma panosuna cevap yazma veya diğer etkinliklere katılmak için zamanları yoktu."

"Bazı ayarladığımız etkinliklere bir kez bile katılmayanlar vardı. Ama bence KAÇD’lerde tamamlama oranı başarı ölçeği sayılabilecek bir etken değil. Çünkü ben de KAÇD ararken \%100 bitirmeyeceğimden emindim."

Sonuç olarak yönetim sürecindeki temel zorlukların katılımcı sayısının fazlalığı ve iş gücü olduğu ortaya çıkmıştır. Katılımcılarla iletişim ve dersle olan ilişkileri ise zorluktan ziyade dikkat edilmesi gereken bir unsur olarak belirtilmiştir.

\section{Değerlendirme}

Değerlendirme konusunda ise tüm katılımcıların yaşadığı temel sorunlar, rapor/ödevleri okumak ve tartışma panosundaki öğrenci gönderilerini okumak için harcanan zamanın oldukça fazla olması olarak ortaya konmuştur. Açık uçlu cevaplar içeren ödevlerin değerlendirmesinde yaşanan zorluk aşağıdaki alıntıda şu şekilde belirtilmiştir:

"Zor olduğunu düşünmüyorum ama zaman tüketici olduğu kesin. Benim üstüme atanmış 20-25 civarı öğrencim vardı ve ödevlerine not vermem gerekiyordu. Fakat tabi ki bir günde yapamadım. Sanırım 6-7 günde tamamladım."

Tartışma panosu değerlendirmesiyle ilgili yaşanan zorluk ise şu şekilde belirtilmiştir:

"Tartışma hazırlanış şekline göre bazen yorucu olabiliyordu. KAÇD ortamında tartışmaları düzenlerken haftalık bir tartışma ödev veriliyordu. Öğrencilerin istediği konuyu seçebilmesi için farklı başlıklar sunuyorduk. Toplamda 1000 gönderi varken her başlıkta birkaç yüz gönderi oluyordu."

Haftalık ortalama her eğitmen başına düşen ve ödevlerin tamamını yapan 25-30 öğrenen düşmesi nedeniyle bu görev eğitmenler açısından bunaltıcı seviyeye ulaşmamıştır. Katılımcılar, eğer daha fazla sayıda öğrenci düzenli şekilde ödev yapsaydı, planlarının akran değerlendirmesini kullanmak olduğunu belirtmişlerdir. Bir katılımcı akran değerlendirmesi fikrini şöyle paylaşmıştır: 
“Bazı KAÇD’lerde 4er kişilik (öğrenci) gruplar diğerlerini değerlendirerek dersi veya modülü geçip geçmediğini belirliyor. Bence konusuna da bağlı olarak bazen çalışabilir ama senden daha fazla bilmeyen biri tarafından değerlendirilmeyi istemezsin. Yani bence bu zorluklardan birisi."

Değerlendirme kısmı ise 3 ana bölümden oluşmaktadır: tartışma panosu, testler (sınavlar) ve projeler. Fakat bu derste eğitmenler sadece dersin başında rozet kazanmak istediğini belirtenleri değerlendirmeye almışlar ve derse her kaydolanı değerlendirmemişlerdir. Tartışma panosunda, ders asistanları içerikle alakalı 3 soru sormaktadır ve öğrencilerden bu soruları cevaplamaları, ek olarak da diğer öğrencilerin gönderilerine katılım sağlamaları beklenmektedir. Her haftanın sonunda, öğrenciler gönderilerinin kalitesine odaklanmadan Geçti/Kaldı sistemine göre değerlendirilmektedir. Eğer 3 tartışmaya da katılmışlarsa geçer not almaktadırlar. Sınav için ise Blackboard isimli öğrenme yönetim sistemi üzerinden testler sunulmakta ve bu sınavlar otomatik notlandırma sistemi ile değerlendirilmektedir. Proje bölümünde ise öğrencilerden rozet kazanabilmeleri için bir projeyi bitirmeleri beklenmektedir. Projelerin büyük gereksinimleri olmamakla birlikte daha fazla öğrenilenleri uygulamaya dökmeye odaklanılmaktadır. Benzer olarak projeler de kalitesine odaklanmadan değerlendirilmektedir. Temel beklenti daha çok içerikle ilgili deneyimleri kapsamasıdır.

Değerlendirme sürecinde ortaya çıkan temel zorluklar ise özellikle nitel değerlendirme sürecindeki zorluklar etrafında toplanmaktadır. Bu unsurda yine katılımcı sayısının fazlalığı göze çarpmakta olup, yapılan değerlendirmelerin kalitesi de yine öğrenen başına düşen eğitmenler ve bu eğitmenlerin bu süreçte gösterdiği performans olarak ortaya çıkmaktadır. Eğitmenler her ne kadar beklentilerinin altında değerlendirme yapmak zorunda kalsalar dahi, bu sürecin bile oldukça zorlayıcı olduğundan bahsetmişlerdir.

\section{TARTIŞMA VE SONUÇ}

Bu çalışmanı amacı, KAÇD ortamında yer alan kişilerin hem öğrenen hem de öğretici perspektifinden yaşadıkları deneyimleri ortaya çıkarmaktır. Öğrenen perspektifinden değerlendirildiğinde KAÇD ortamlarının kullanım amaçlarına yönelik literatürde yer alan çalışmaların sonuçlarıyla benzer sonuçlar bulunmuş ve bu sonuçlar temelde bireysel ve profesyonel gelişim (Zutshi, O’Hare ve Rodafinos, 2013; Liu, Kang ve McKelroy, 2015) ile destek materyal temin etmek (Liu, Kang ve McKelroy, 2015), kolay ve ücretsiz erişim ile esneklik (Liu, Kang ve McKelroy, 2015; Deshpande ve Chukhlomin, 2017) olarak sınıflandırılmıştır. Katılma nedenlerinin yanı sıra bu derslerin sunduğu avantajların da genellikle profesyonel ve mesleki beceri gelişimine, ücretsiz kaynak erişimine ve sosyal iletişim ve sosyal iletişim ağı oluşturmaya olanak sağlaması olduğu belirtilmiştir. Katılımcıların hepsinin üniversite mezunu ve lisansüstü seviyede eğitimlerine devam ettikleri düşünüldüğünde, çıkan sonuçların literatürde de belirtilen katılımcı profilleriyle uyuştuğu gözlemlenmektedir (Macleod vd., 2015). Ayrıca bu derslerin sunduğu avantajlar arasında sosyal iletişim ağının gelişmesine katkı sağlaması, katılımcıların profesyonel mesleki deneyimlerine de katkı sağladığı olarak değerlendirilebilir. Eğitmen perspektifinden değerlendirildiğinde ise yine mesleki gelişim vurgusu göze çarpmaktadır. Değişen öğrenme ortamları ve yeni nesil öğretim tasarımı uygulamaları konusunda deneyim sahibi olabilmek, bu uygulamayı tasarlayanlar için önemli motivasyon kaynakları olarak düşünülebilir. (Sari, Bonk ve Zhu, 2020). Ek olarak, KAÇD ortamlarının ücretsiz olması hem eğitmenlere hem öğrencilere rahatıı ve esneklik sağlamaktadır. Öğrenciler geçme/kalma kaygısı olmayan derslere daha rahat şekilde katılmaktadır. Bu çalışmada, öğrenenlerin özellikle ücretsiz ve erişilebilir kaynaklara ulaşım, öğrenme ağlarını ve uygulayıcı toplulukları genişletme konularında KAÇD’lere yönelik olumlu görüşleri olduğu ortaya çıkmıştır.

Öğrenenlerin karşılaştıkları sorunlar ise literatürde de benzer şekilde ifade edildiği gibi (Park, Jung ve Reeves, 2015) iletişim, motivasyon olarak ortaya çıkmıştır. Bulgulara göre, ihtiyaca yönelik bilgilere erişim katılımcıların tüm dersi takip etme yönündeki motivasyonlarını etkilerken, iletişim anlamındaki zorlukların da özellikle iletişim kanallarının eksikliği ve iletişim kanallarında düzenli bir akışın sağlanamaması olarak belirtilmiştir. Bazı katılımcılar sosyal medya ve tartışma panoları gibi ortamları bir etkileşim yöntemi ve ilgi arttırıcı olarak görürken, bazı katılımcılar ise fazla öğrenci sayısını, tartışmaların çok fazla sayıda olması ve fazla sayıda ödev olmasını dikkat dağıtıcı, dersten uzaklaştırıcı olarak gördüklerini belirtmişlerdir. Bu noktada, iletişim sürecinin yönetilmesi ve öğrenenlerin derse dahil edilmeleri özellikle eğitmenlerin incelemesi gereken unsurlar olarak ön plana çıkmaktadır. Öğrenenlerin karşılaştıkları zorluklardan farklı olarak ise eğitmenlerin karşılaştıkları zorluklar 3 temel aşamada incelenmiştir: tasarım, uygulama ve değerlendirme.

Eğitmenler tasarım sürecinde özellikle konu ve içeriğin belirlenmesini en zorlayıcı kısımlardan birisi olarak nitelendirmişlerdir. Öğretim sürecinin nasıl tasarlanacağı, öğretim metotlarının ve ölçme değerlendirme unsurlarının nasıl işleneceği ise zorluk olarak nitelendirilmemiştir. Bu süreçte eğitmenlerin çevrimiçi eğitim deneyimlerinin olmasının, bu unsurları tasarlamada kolaylık sağlamış olduğu düşünülebilir. Çünkü bu süreçte belirtilen zorluklar, öğretimin nasıl sağlanacağından çok, geniş ölçekli katılımcılarla bu sürecin nasıl yürütüleceğine dair zorluklarda oluşmaktadır. Belirli sayıdaki katılımcı ile sürdürülen geleneksel çevrimiçi öğrenme ortamlarına nazaran, KAÇD ortamlarındaki katılımcılar, süreci en çok zorlayan unsurlar olarak karşımıza çıkmaktadır. Stracke vd.'nin (2018) çalışmasında çıkan sonuçlara göre, öğrenenlerle öğreticilerin amaçları ve deneyimleri arasında farklılıklar bulunmaktadır. Öğreticilerin öğrenenlerin istek ve ihtiyaçlarını yeterince anlayamadığı ve öğrenenlerin iletişim isteklerini yeterince anlamlandırmadıklarını ortaya çıkmıştır. Bu çalışmada ise, çalışılan gruptakilerin çoğunluğunun daha önceden öğrenen deneyimleri olması, tasarım ve uygulama sürecinin belirlenmesinde önemli bir etkiye sahip olduğu belirlenmiştir. Bu etki, kendi deneyimlerinden yola çıkarak bazı stratejilerin uygulanmasını sağlamıştır. Bu etkinin gözlemlendiği ilk unsur öğrenen grubu profili ve dersi tamamlama arasındaki ilişkidir. KAÇD ortamlarında derse kayıt olma ve sorumluluklar geleneksel eğitimdeki kadar katı değildir (DeBoer, Ho, Stump ve Breslow, 2014). Dolayısıyla bu durum öğrenme stilleri ve karakteristikleri hakkında belirsizlikler 
oluşturmaktadır. Öğrenci karakteristiklerindeki, öğrenme stillerindeki, önbilgilerindeki ve dillerindeki bu çeşitlilikler öğretimi tasarlaması sorunlu ve zor hale getirmektedir. Fakat, açık/net belirlenmiş hedef ve kazanımlarla, çevrimiçi dersler daha başarılı ve tatmin edici olarak tasarlanabilir (Toven-Lindsey, Rhoads ve Lozano, 2015). Bulgulara dayanarak KAÇD ortamında ders oluştururken yaşanan en önemli zorluklardan birinin öğrencilere açık/net rehberlik ve yol haritası sunmak olduğu ortaya çıkmıştır. Ancak, öğreticiler, kendi deneyimlerinden yola çıkarak öğrenen grubunun farklı motivasyon, kullanım amacı ve bilgi ihtiyacı olabileceği konusunda hemfikirlerdir. Bu duruma bakış açıları, dersi bırakma yüzdesinin fazlalığına yönelik perspektiflerinde daha akılcı çıkarımlar yapmalarına neden olmuştur. Ayrıca, belirledikleri hedef kitle lisans mezunu ve spesifik konuyu öğrenme motivasyonu olan kişiler olarak tanımlanmıştır. Bu nedenle, bu çalışmada dersi bırakma unsuru bir zorluk olarak tanımlanmamıştır. Ek olarak, kullanıcı profili farkındalığı, dersin içeriğini belirlerken daha spesifik ve mesleki beceriye yönelik bir konu seçimine yol açmıştır. Tüm bunlara rağmen literatürde belirtildiği üzere derse kaydolanların \%10'undan daha azı dersi tamamlamaktadır (Cordero, Jordan, Sanabria ve Torregrosa, 2015; Parr, 2013; Alraimi, Zo ve Ciganek, 2015). Ancak, bazı çalışmalarda dersi tamamlamayan öğrenciler pusucular (ing. lurkers) olarak (Breslow vd., 2013) veya "eğilimi takip edenler" olarak tanımlanmıştır. Eğilimi takip edenler geride kalmamak için derse kaydolurken, pusucular ihtiyacı olan ücretsiz kaynaklara ulaşmamak için derse kaydolup bitirmemektedirler. Bazı öğrencilerin dersin sadece belirli bir bölümüne ihtiyacı olduğu için derse kaydolup tamamlamadığı söylenebilir (Fini, 2009; Siemens, 2013). Dolayısıyla yüksek bırakma oranlarına sahip KAÇD’lerin başarısını değerlendirmede bu unsur yeterince etkili bir faktör olarak görülmeyebilir.

Katılımcı fazlalığının yarattığı bazı sorunlar özellikle tasarım (hedef kitle, konu ve içerik belirleme), yönetim ve uygulama (ölçme değerlendirme) aşamalarında bazı zorluklar yaratsa da özellikle yönetim ile ilgili kategoride katılımcılarla iletişim anlamında dil problemi yanı sıra iletişim kanallarından ziyade katılımcı hareketlerini takip etmedeki zorluk olarak belirtilmiştir. Bu unsur, öğrenenler açısından var olan endişelerin tasarım sürecinde giderilmeye çalışması olarak sürece yansımıştır. Bu noktada eğitmenlerin katılımcılarla iletişim konusuna özellikle odaklanmaları ve farklı stratejiler üretmeleri (tartışma panoları, webinarlar, sosyal medya platformları), iletişim bağlamındaki unsurları zorluktan ziyade dikkat edilmesi gereken bir unsur olarak belirtmelerine yol açmıştır. Ek olarak, öğrenenlerin ortama dahil olmalarını sağlamak ve dersin katılımcı sayısını arttırmak için rozet sistemini kullanmışlardır ki bu yaklaşım başka çalışmalarda da benzer şekilde karşımıza çıkmaktadır (Sari, Bonk ve Zhu, 2020). Buna rağmen etkinliklere katılımın beklentinin altında olduğu ifade edilmiştir. Bunun nedeni, katılımcıların çoğunun önceden de bahsettiği eğitimi takip eden öğrenenler olabileceği gibi öğrencilerin sadece ihtiyaç duydukları bilgiyi aldıkları ve sadece tartışmaları takip etme motivasyonlarına sahip olabilecekleri belirtilebilir. Ancak tüm tasarım ve uygulama adımlarını içeren bu süreçte karşılaşılan en büyük zorluklardan birisi zaman, destek ve emek gerektiren iş gücü dağılımıdır. Diğer çalışmalarda da benzer sonuçlarla ifade edildiği üzere (Evans ve Myrick, 2015; Zhu, Bonk ve Sari, 2018) bu ölçekte bir dersin yürütülmesi yoğun bir zaman ve iş yükünü de beraberinde getirmektedir. Bu nedenle, bireysel adımların yerine farklı işlerde uzmanlaşmış bir takım dahilinde bu dersin tasarlanması derslerin sürdürülebilir olması açısından faydalı olacaktır. Son olarak finansal sıkıntılar öğrenen ve öğretici deneyimleri arasında ciddi bir farkın oluşmasına neden olmaktadır. Ücretsiz hatta açık kaynak olarak sunulması hedeflenen derslerin çoğunun mevcut sistemde organizasyonlar, şirketler ve üniversiteler üçgeninde yer alan çoğu kâr amaçlı kuruluşun sunduğu platformlar çerçevesinde katılımcılara ulaştırılması, istenen durumun beklentinin oldukça altında kaldığını göstermektedir (Yuan ve Powell, 2013). Öğrenenlerin ciddi bir yüzdesinin halihazırda yükseköğretim derecesine sahip olan kişiler olmasına rağmen sertifika veya diploma ihtiyacına sahip olmaları da halihazırda yetişkin öğrenenlerin motivasyonları arasındadır. Dolayısıyla bu çalışmada yer alan kişilerin herhangi bir finansal kaynak almadan ürettiği bu dersin zaman ve para açısından sürdürülebilirliği oldukça tartışmalıdır.

Değerlendirme sürecindeki zorluklar ise eğitmenler açısından hangi tekniklerin kullanılacağından ziyade değerlendirme sürecinde harcanan emek ve zaman unsuru ile değerlendirmenin kalitesi olarak ortaya çıkmıştır. Bu uygulamada farklı türdeki ölçme ve değerlendirme teknikleri kullanılmış olup (otomatik notlandırma, tartışma notları, raporlar), bu süreç her bir modüle özgü olarak tasarlanmıştır. KAÇD’lerin çoğunluğunda otomatik notlandırma testleri kullanılmaktadır. Bu tipteki değerlendirme hızlı bir sonuç sunsa da temel sorun, bu uygulamaların değerlendirmenin kalitesini düşürmesidir (Zhu, Bonk ve Sari, 2018). Eğer açık uçlu değerlendirme tercih edilirse bu kez de sorun zaman ve emek ihtiyacının çok yükselmesi olarak ortaya çıkmaktadır. Açık uçlu değerlendirme için de kullanılan bazı otomatik değerlendirme sistemleri sağlam sonuçlar verse de kalitesi ve performansı belirsizdir (Hew ve Cheung, 2014). Spector (2014) KAÇD'lerde biçimlendirici ve toplam değerlendirmeleri incelemiş ve KAÇD'lerin çoğunluğunda bilginin uygulanması seviyesi yerine en temel bilgi seviyesinde değerlendirme kullanıldığını belirtmiştir. Benzer olarak, bu çalışmadaki eğitmenler de ödevlerin içerik kalitesine göre değil, tamamlanıp tamamlanmadığına bakılarak değerlendirildiğini söylemiştir. Bunun sebebi ise zaman yetersizliği olarak belirtilmiştir. Yüksek katılımcılı bu derslerde verilen ödevlerin değerlendirilmesi dersin kalitesinin ve öğrencilerin başarılarının değerlendirilmesinde endişelerin başını çekmektedir (Xiong ve Suen, 2018). Ancak bu süreçte, ölçme ve değerlendirme sürecinin kalitesini arttırmak için, literatürde de belirtilen hazır değerlendirme sistemlerinin yanında nitel değerlendirme unsurları da sürece dahil edilmiştir (rapor, proje, tartışma ortamı cevapları gibi) ancak yine bu noktada da nitel değerlendirmede ayrılabilecek zaman konusunda sıkıntı yaşanmıştır. Najafi, Rolheiser, Harrison ve Haklev'in (2015) çalışmasında belirttiğine benzer şekilde bu çalışmada da takım yaklaşımının tasarım ve uygulama sürecindeki zaman problemini çözmede önemli bir unsur olduğu ortaya çıkmıştır. Belirtilen sorunu çözmek için de hem tasarım hem de uygulama sürecinde öğreticiler takımlara ayrılmış ve her takım belirli işlerden ve belirli öğrenci gruplarından sorumlu olacak şeklide iş tanımları yapılmıştır. Ek olarak sadece süreci tamamlayıp rozet almak isteyenler için nitel değerlendirmelerin yapılması iş yükünü azaltmış fakat diğer katılımcıların ödevlerinin değerlendirilememesine yol açmıştır. Eğitmenlerin düşündüğü ek yöntem olan akran değerlendirmesi yöntemi ise literatürde oldukça sık bahsedilen bir yöntemdir. Fakat

| Kastamonu Eğitim Dergisi, 2020, Vol. 28, No. 6| 
değerlendiricilerin farklı bilgi birikimleri nedeniyle geçerliliği sorgulanan bir yöntem olmakla beraber bu değerlendirmeye dair öncül bir puanlama kriteri hazırlanması (Najafi, Rolheiser, Harrison ve Haklev, 2015) veya benzer motivasyon veya amaca sahip küçük çaplı değerlendirme grupları oluşturulması (Xiong ve Suen, 2018) önerilen stratejiler arasındadır.

Bu çalışma öğrenen ve öğretici deneyimlerini ve bu deneyimler dahilinde şekillenen görüşleri sunmayı amaçlamıştır. Spesifik olarak öğrenen ve eğitmen perspektiflerinden değerlendirildiğinde mesleki gelişim ve bilgi edinme ihtiyacı KAÇD’ler hakkındaki olumlu görüşleri desteklerken, eğitmenlerin yaşadığı zorluklar açısından tasarım, uygulama ve değerlendirme süreçleri göz önünde bulundurulabilir. Bu noktada ortaya çıkan zorlukların temelde öğrenen sayısının, niteliğinin ve beklentilerinin geniş ölçekli olması ile ilişkili olduğu belirtilebilir. Çevrimiçi öğrenme deneyimi olan eğitmenlerin karşılaştıkları zorluklar bu ortamların nasıl tasarlanacağına yönelik pedagojik unsurlardan ziyade, bu unsurların geniş katılımcılı ortamlarda nasıl sunulabileceğine dair durumları içermektedir. Karşılaşılan engellere yönelik geliştirilen stratejiler de bu durumlarda yer alan sorunları çözmeye yönelik atılmış adımlar olarak incelenebilir. Tasarım sürecinde hedef kitlenin belirlenmesi ve bu kitlenin spesifik amaçları ve beklentilerinin belirlenmesi önemli olabilir (Bu çalışmada hedeflenen kitlenin derslerinde sosyal medya kullanmayı amaçlayan eğitimciler örneğinde olduğu gibi). Haftalar bazında bölünen içeriklerin ve uygulamaların tasarlanmasında takım çalışmasına ihtiyaç duyulduğu ve bu takımların görev tanımlarının yapılmasının önemli olduğu söylenebilir. Uygulama aşamasında ise, özellikle ders sürecinin tasarımı ve iletişim ortamlarının düzenlenmesi dikkat edilmesi gereken unsurlar olarak öne çıkmaktadır. Öğrenenlerin iletişime ve etkileşime önem verdiği bu ortamlarda farklı iletişim kanallarının kullanılmasının yanında bu iletişimdeki düzen ve takip sürecinin özellikle önemli olduğu vurgulanabilir. Farklı kanallar ve düzenli hatırlatmalarla öğrencilerin derse katılımının attırılması konusunda faydalı olabilir. Bu noktada takımdaki eğitmenlerin bu tartışmaları yönetme ve takip becerileri düşünülmesi gereken en önemli unsur olarak karşımıza çıkmaktadır. Değerlendirme sürecinde belirlenen stratejiler ve katılımcıların nispeten azlığı bu süreçteki zorluk derecesini azaltsa da özellikle nitel değerlendirme sürecinde akran değerlendirmesi ve düzenli katılım profili sunun öğrencilerin değerlendirilmesi kullanılabilecek stratejiler olarak sunulabilir. Eğitmenler açısından yaşanan en büyük zorluklardan birisi olan zaman sıkıntısı, mali problemler ve iş gücü problemleriyle bağlantılı olarak KAÇD ortamları dahilinde gerçekleştirilen bireysel uygulamalarının devamlılı̆ının sağlanması düşünülmesi gereken önemli noktalardan birisidir. Bu hareket dahilinde yer alan iş modellerinin yanı sıra özellikle yüksek öğretim kurumlarında çalışan eğitmenlerin finansal ve iş gücü anlamında desteklenmesi konusunda üniversitelere büyük görevler düşmektedir. Sonuç olarak, hem öğrenen hem eğitmen perspektifinden değerlendirildiğinde, daha öncesinde öğrenen deneyimi yaşayan kişilerin, KAÇD ortamlarını tasarlama ve uygulama aşamasında yaşanan engeller ve zorluklar hakkında daha bilinçli oldukları ve öğrenenlerin ihtiyaçlarını daha iyi analiz edebilmek için kendi deneyimlerinden yararlandıkları çıkarımı yapılabilir. Ayrıca, KAÇD’lerin sunduğu olanaklar, kısıtlamalar konusunda da farkındalıklarının yüksek olduğu belirtilebilir. Öğrenen profillerini, başarılarını ve uygulamaların başarılarını belirlemeye yönelik çokça çalışmanın bulunduğu literatürde, bu çalışmanın, eğitmenlerin deneyimleri, yaşadıkları engeller ve uygulanabilecek stratejiler hakkında gelecek çalışmalara ışık tutabileceği düşünülmektedir. Gelecek çalışmalarda nitel ve nicel verilerin harmanlandığı ve daha fazla durum içeren çalışmaların yapılması özellikle öğreticilerin karşılaştığı engellerin aşılmasına ve öğrenci perspektifinin daha etkili şekilde yorumlanmasına olanak tanıyabileceği düşünülmektedir.

\section{Etik Kurul Onay Bilgileri}

Bu çalışmanın etik kurul onayı 2015 yılında Florida State University İnsan Araştırmaları Komitesi tarafından verilmiştir. Başvuru numarası 2015.15894 olarak tanımlıdır.

\section{Teşekkür}

Bu çalışmanın yapılmasını 2214-A numaralı doktora sırası araştırma bursuyla mümkün kılan TÜBiTAK'a teşekkürlerimizi sunarız

\section{KAYNAKÇA}

Alario-Hoyos, C., Pérez-Sanagustín, M., Cormier, D., \& Kloos, C. D. (2014). Proposal for a conceptual framework for educators to describe and design MOOCs. Journal of Universal Computer Science, 20(1), 6-23.

Allen, I. E., \& Seaman, J. (2014). Grade change: Tracking online education in the United States. Oakland, CA: Babson Survey Research Group and Quahog Research Group LLC.

Alraimi, K. M., Zo, H., \& Ciganek, A. P. (2015). Understanding the MOOCs continuance: The role of openness and reputation. Computers \& Education, 80, 28-38.

Askeroth, J.H., \& Richardson, J.C. (2019). Instructor perceptions of quality learning in MOOCs they teach. Online Learning, 23(4), 135-159. doi:10.24059/olj.v23i4.2043

Belanger, Yvonne; \& Thornton, Jessica (2013). Bioelectricity: A Quantitative Approach Duke University's First MOOC. Retrieved from https://hdl.handle.net/10161/6216.

Branch, R. M., \& Dousay, T. A. (2015). Survey of instructional design models (5th ed.). Bloomington, IN: Association for Educational Communications \& Technology.

Breslow, L., Pritchard, D. E., DeBoer, J., Stump, G. S., Ho, A. D. \& Seaton, D. T. (2013). Studying learning in the worldwide classroom: research into edX's first MOOC. Research \& Practice in Assessment, 8, 13-25. 
Bonk, C. (2016). Keynote: What is the state of e-learning? Reflections on 30 ways learning is changing. Journal of Open, Flexible and Distance Learning, 20(2), 6-20.

Clark, D. (2013). MOOCs: Taxonomy of 8 types of MOOC. Donald Clark Plan B [Blog post]. Retrieved from http://donaldclarkplanb.blogspot.co.uk/2013/04/moocs- taxonomy-of-8-types-of-mooc.html

Conole, G. (2014). A new classification schema for MOOCs. The International Journal for Innovation and Quality in Learning, 2 (3), 65-77.

Cordero, A., Jordan, C., Sanabria, E., \& Torregrosa, J. R. (2015). Towards a Better Learning Models Through OCWs and MOOCs. International Journal of Artificial Intelligence and Interactive Multimedia, 3(4).

Creswell, J. W. (2012). Educational research: Planning, conducting, and evaluating quantitative and qualitative research (4th ed.). Upper Saddle River, NJ: Pearson.

D'Antoni, S. (2008). Open Educational Resources the way forward, deliberations of an international community of interest. UNESCO. Retrieved from http://stoa.usp.br/liliansta/files/-1/2843/OER+Way+Forward+final+version.pdf

DeBoer, J., Ho, A. D., Stump, G. S., \& Breslow, L. (2014). Changing “Course”: Reconceptualizing Educational Variables for Massive Open Online Courses. Educational Researcher, 43(2), $74-84$.

Deshpande, A. \& Chukhlomin V. (2017). What Makes a Good MOOC: A Field Study of Factors Impacting Student Motivation to Learn. American Journal of Distance Education, 31(4), 275-293, doi: 10.1080/08923647.2017.1377513

Downes, S. (2012). Connectivism and connective knowledge: Essays on meaning and learning networks. Retrieved from https://www.oerknowledgecloud.org/archive/Connective_Knowledge-19May2012.pdf

Driscoll, M. (2000). Psychology of learning for instruction (2nd ed.). Boston, MA: Pearson.

Duval, E., \& Wiley, D. (2010). Guest Editorial: Open Educational Resources. IEEE Transactions on Learning Technologies, 3 (2), 83-84.

Evans, S., \& Myrick, J. G. (2015). How MOOC instructors view the pedagogy and purposes of massive open online courses. Distance Education, 36(3), 295-311. doi:10.1080/01587919.2015.1081736

Fini, A. (2009). The technological dimension of a massive open online course: The case of the CCK08 course tools. International Review of Research in Open and Distance Learning, 10(5), 1-26.

Hew, K. F., \& Cheung, W. S. (2014). Students' and instructors' use of massive open online courses (MOOCs): Motivations and challenges. Educational Research Review, 12, 45-58.

Jacoby, J. (2014). The disruptive potential of the Massive Open Online Course: A literature review. Journal of Open, Flexible and Distance Learning, 18(1).

Kizilcec, R. F., Piech, C., \& Schneider, E. (2013). Deconstructing Disengagement: Analyzing Learner Subpopulations in Massive Open Online Courses. In Proceedings of the Third International Conference on Learning Analytics and Knowledge, LAK 2013. Leuven, Belgium.

Liu, M., Kang, J., \& McKelroy E. (2015). Examining learners' perspective of taking a MOOC: reasons, excitement, and perception of usefulness, Educational Media International, 52(2), 129-146, doi: 10.1080/09523987.2015.1053289

Liyanagunawardena, T. R., Lundqvist, K., Mitchell, R., Warburton, S., \& Williams, S. A. (2019). A MOOC Taxonomy Based on Classification Schemes of MOOCs. European Journal of Open Distance and E-Learning, 22(1), 85-103.

Lowenthal, P., Snelson, C., \& Perkins, R. (2018). Teaching massive, open, online, courses (MOOCs): Tales from the front line. International Review of Research in Open and Distributed Learning, 19(3). doi:10.19173/irrodl.v19i3.3505

Macleod, H., Haywood, J., Woodgate, A., \& Alkhatnai, M. (2015). Emerging patterns in MOOCs: Learners, course designs and directions. TechTrends: Linking Research \& Practice to Improve Learning, 59, 56-63. doi:10.1007/s11528-014-0821-y

McAuley, A., Stewart, B., Siemens, G. \& Cormier, D. (2010). The MOOC model for digital practice. University of Prince Edward Island. Retrieved from https://oerknowledgecloud.org/sites/oerknowledgecloud.org/files/MOOC_Final.pdf

Means, B., Toyama, Y., Murphy, R., Bakia, M., \& Jone, K. (2010). Evaluation of Evidence-Based Practices in Online Learning: A Meta-Analysis and Review of Online Learning Studies. U.S. Department of Education, Office of Planning, Evaluation, and Policy Development. Washington, D.C

Milheim, W. D. (2013). Massive Open Online Courses (MOOCs): Current Applications and Future Potential. Educational Technology, 53(3), 3842.

Murphy, A. (2013). Open educational practices in higher education: Institutional Adoption and Challenges. Distance Education , 34 (2), $201-217$.

Najafi, H., Rolheiser, C., Harrison, L., \& Håklev, S. (2015). University of Toronto instructors' experiences with developing MOOCs. The International Review of Research in Open and Distributed Learning, 16(3). doi:10.19173/irrodl.v16i3.2073

O'Connor, K. (2014). MOOCs, institutional policy and change dynamics in higher education. Higher Education, 68(5), 623-635.

Park, Y., Jung, I., \& Reeves T. C. (2015) Learning from MOOCs: a qualitative case study from the learners' perspectives. Educational Media International, 52(2), 72-87, doi: 10.1080/09523987.2015.1053286

Parr, C. (2013). Coursera founder: Mooc credits aren't the real deal. Times Higher Education, Retrieved from: https://www.timeshighereducation.com/coursera-founder-mooc-credits-arent-the-real-deal/2001085.article

Peter, S., \& Deimann, M. (2013). On the role of openness in education: A historical reconstruction. Open Praxis, 5(1), 7-14.

Pilli, O., \& Admiraal, W. (2016). A taxonomy for Massive Open Online Courses. Contemporary Educational Technology, 7(3), $223-240$.

Pozon-Lopez, I, Higueras-Castillo, E., Munoz-Leiva, F., \& Liebana-Cabanillas, F. J. (2020). Perceived user satisfaction and intention to use massive open online courses (MOOCs). Journal of Computing in Higher Education. https://doi.org/10.1007/s12528-020-09257-9

Richter, S. L., \& Krishnamurthi, M. (2014). Preparing Faculty for Teaching a MOOC: Recommendations from Research and Experience. International Journal of Information and Educational Technology, 4(5).

|Kastamonu Eğitim Dergisi, 2020, Vol. 28, No. 6| 
Sanchez-Gordon, S., \& Luján-Mora, S. (2014, March). MOOCs gone wild. Proceedings of the 8th International Technology, Education and Development Conference (INTED 2014), p. 1449-1458, Valencia (Spain).

Sari, A. R., Bonk, C. J., \& Zhu, M. (2020). MOOC instructor designs and challenges: what can be learned from existing MOOCs in Indonesia and Malaysia? Asia Pacific Education Review, 21, 143-166.

Siemens, G. (2013). Massive Open Online Courses: Innovation in education? In McGreal, R., Kinuthia W., \& Marshall S. (Eds.). Open Educational Resources: Innovation, Research and Practice. Commonwealth of Learning: Athabasca University

Spector, J. M. (2014). Remarks on MOOCs and Mini-MOOCs. Educational Technology Research Development, 62(385), $385-392$.

Stracke, C. M., Texeira, A. M., Vassiliadis, B., Tan, E. Pinto, M. T., Kameas, A., \& Sgouropoulou, C. (2018). Gap between MOOC designers' and MOOC learners' perspectives on interaction and experiences in MOOCs: Findings from the Global MOOC Quality Survey 2018 IEEE $18 t h$ International Conference on Advanced Learning Technologies (ICALT), Mumbai, 2018, pp. 1-5, doi: 10.1109/ICALT.2018.00007.

Toven-Lindsey, B., Rhoads, R. A., \& Lozano, J. B. (2015). Virtually unlimited classrooms: Pedagogical practices in massive open online courses. Computers \& Education, 24, 1-12.

Veletsianos, G., \& Shepherdson, P. (2016). A systematic analysis and synthesis of the empirical MOOC literature published in 2013-2015. The International Review of Research in Open and Distributed Learning, 17(2). http://dx.doi.org/10.19173/irrodl.v17i2.2448

Weller, M., Jordan, K., DeVries, I., \& Rolfe, V. (2018). Mapping the Open Education Landscape: Citation Network Analysis of Historical Open and Distance Education Research. Open Praxis, 10(2), 109-126. https://doi.org/10.5944/openpraxis.10.2.822

Wiley, D. (2014, March 5). The Access Compromise and the 5th R [blog post]. Iterating toward openness. Retrieved from https://opencontent.org/blog/archives/3221

Xiong, Y, \& Suen, H. K. (2018). Assessment approaches in massive open online courses: Possibilities, challenges and future directions. Int Rev Educ, 64, 241-263. https://doi.org/10.1007/s11159-018-9710-5

Yin, R. K. (2009). Case Study Research Design and Methods. California: Sage Publications, Inc.

Yuan, L., \& Powell, S. (2013). MOOCs and Open Education: Implications for Higher Education. JISC CETIS. doi:10.13140/2.1.5072.8320.

Zhu, M., Bonk, C.J., \& Sari, A.R. (2018). Instructor experiences designing MOOCs in higher education: Pedagogical, resource, and logistical considerations and challenges. Online Learning, 22(4), 203-241. doi:10.24059/olj.v22i4.1495

Zutshi, S., O'Hare, S., \& Rodafinos, A. (2013). Experiences in MOOCs: The Perspective of Students. American Journal of Distance Education, 27, 218-227. 